\title{
2017 年日本地理学会春季学術大会プログラム
}

\section{1. 大会日程}

3 月 27 日 (月) 15 時 00 分 16 時 30 分 3 月 28 日 (火) 9 時 00 分 17 時 00 分 10 時 00 分 17 時 00 分

13 時 00 分 16 時 00 分

13 時 00 分 16 時 15 分

13 時 00 分 17 時 00 分

13 時 00 分 16 時 00 分

17 時 00 分 17 時 30 分 16 時 15 分 17 時 45 分 18 時 00 分 20 時 00 分

3 月 29 日 (水) 9 時 00 分 12 時 00 分 9 時 00 分 15 時 00 分

13 時 00 分 17 時 00 分

13 時 00 分 16 時 00 分

13 時 00 分 16 時 00 分

13 時 00 分 17 時 00 分

13 時 00 分 16 時 40 分

13 時 00 分 16 時 30 分

13 時 00 分 17 時 00 分

13 時 00 分 17 時 00 分
臨時総会·代議員会 $(3 B 302)$

口頭発表

ポスター発表 (説明・討論は 3 月 28 日および 29 日 12 時 から 12 時 30 分の間に行います)

地理教育公開講座：「地理総合」（仮）と GIS（地理情報 システム）(第 0 会場）（日本地理教育学会共催）

シンポジウム S01: 熊本地震からわれわれは何を学ぶベ きか——地理学からの発信——(第 1 会場)（日本地理学 会災害対応委員会主催公開シンポジウム)

シンポジウムS02：自然環境の保全と活用に関する国際 的制度の諸相 (第 2 会場)（日本地理学会ジオパーク対応 委員会主催公開シンポジウム)

シンポジウムS03：地名標準化の現状と課題——地名委 員会（仮称）の設置に向けて—(第 3 会場）(日本地理 学会理事会主催公開シンポジウム)

表彰式（第 0 会場）

GIS 講習会

懇親会（第二エリア食堂）

口頭発表

ポスター発表 (説明・討論は 12 時から 12 時 30 分の間 に行います)

シンポジウム S04：山岳科学の創出——山岳地域の諸問 題を分野横断で俯瞰する一 (第 0 会場)（日本地理学会 理事会主催公開シンポジウム)

シンポジウム S11：地理学のアウトリーチ・科学コミュ ニケーション活発化のために（第 1 会場）

シンポジウム S12：滋賀県朽木に抢けるトチノキ利用か らみた人と自然の関わり（第 2 会場）

シンポジウム S13：農村空間の商品化は地域活性化につ ながるか——カナ゙と日本の事例——(第 3 会場)

シンポジウムS14：黑潮の道——地域学的比較研究をめ ざして——(第 4 会場 $)$

シンポジウム S15：データレスキューによるアジアの気 候変動解明（第 5 会場）

シンポジウムS16：暑熱分野における気候変動影響と適 応技術の社会実装（第6 会場）

研究グループ集会

巡検第 1 班, 巡検第 2 班, 巡検第 3 班, GIS 講習会

3 月 30 日 (木) 


\section{2. 大会会場}

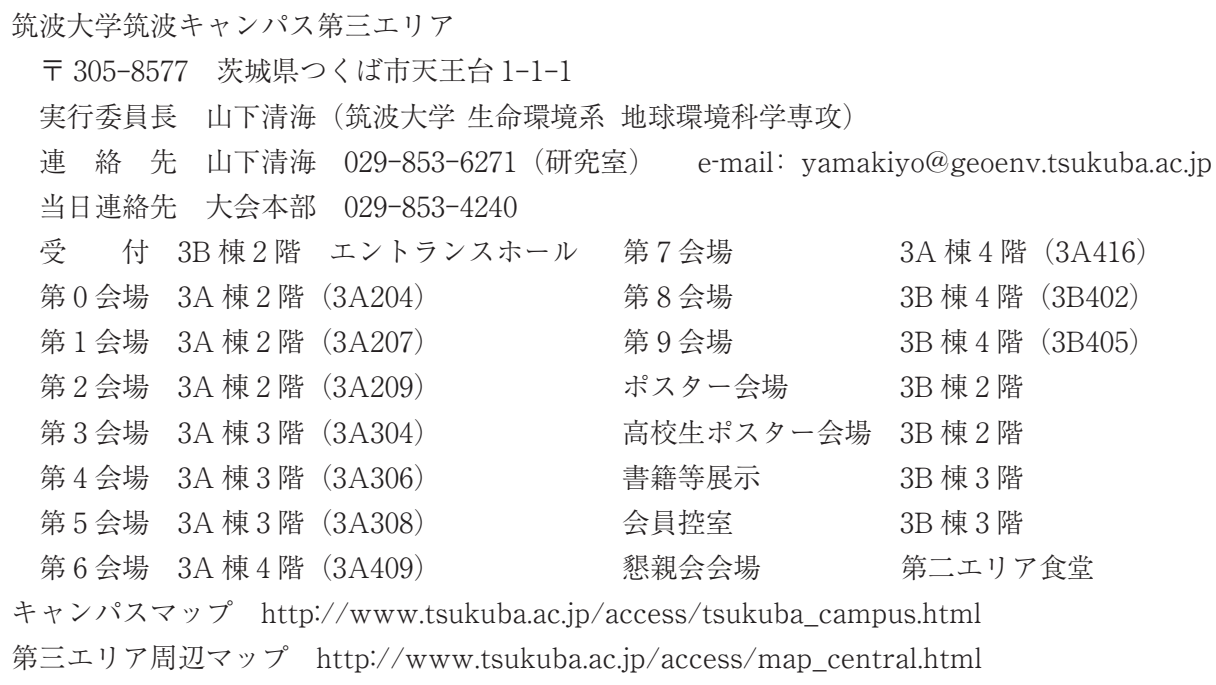

\section{3. 会場への交通案内}

つくばエクスプレス（TX）つくば駅下車，A3 出口からつくばセンターバスターミナル 6 番乗り場へ. 関 東鉄道バス筑波大学中央ゆき，または筑波大学循環（右回り，左回り）に乗り「第三エリア前」バス停下車， 徒歩 3 分.（ただし右回りは左回りより 10 分弱早い)

お車でお越しの方は，第三エリア北側の駐車場を御利用下さい。 大会期間中ゲートは開放しておりますの で，駐車証の発行は必要ありません，

筑波キャンパスへの交通アクセス http://www.tsukuba.ac.jp/access/tsukuba_access.html

\section{4. 大会参加の諸費用}

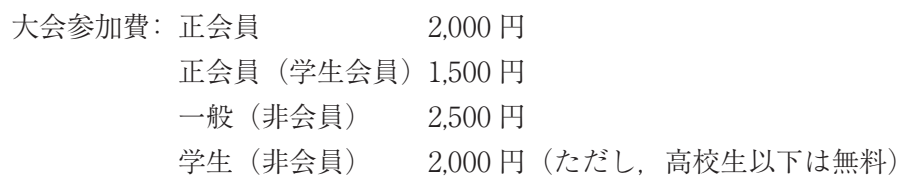

懇親会費 : 5,000 円（院生・学生 3,000 円）

発表要旨集：2,000円 会場受付で販売します.

大会参加費と懇親会費の領収証発行は省略し, 参加証（名札）の発行をもって代えます。特に, 領収証を必 要とされる方は, 受付手続きの際にお申し出下さい.

\section{5. 食事の案内}

会場周辺（キャンパス内）に，食堂・売店等がありますので，御利用下さい,

\section{6. 託児所について}

以下の託児所に参加者個人でお申し込み下さい.

・チャイルド・クラブ・パンセ

(電話 029-861-1500ＵRL http://www.childclub.e-tsukuba.jp/index.htm)

TXつくば駅併設のつくばセンターバスターミナル 4 番乗り場より関東鉄道バス「学園南循環（右回り，左 回り)」に乗車し (乗車時間 5 分), 「二の宮一丁目」バス停で下車し徒歩 1 分のところにあります。託児を御希 望の方は，上記 URL を御参照の上，1週間前くらいまでに上記番号にお電話で「一時預かり」をお申し込み下 さい. 当日の予約人数が定員を超えた場合はお受けできない場合もあります。（3 月 28 日，29 日両日可能） 


\section{7. 巡検の集合時間・場所}

第 1 班 筑波山地域ジオパークをあるく・みる・きく—自然と人をつなぐ石，土，水を楽しむ—

3 月 30 日（木） 9 時 TXつくば駅前

第 2 班＼cjkstart鬼怒川・小貝川低地の地形変遷とその地域の水害と地盤災害

3 月 30 日（木） 9 時 TXつくば駅前

第 3 班 研究学園都市 50 年と重伝建真壁

3 月 30 日（木） 9 時 筑波大学中央・本部棟前， 9 時 15 分 $\mathrm{TX} く は ゙$ 駅前

\section{8. 口頭発表について}

人名の*印は口頭発表者を示します。発表時間は討論・交替時間を含めて 19 分とし, 1 鈴 12 分, 2 鈴 15 分 (発表終了), 終鈴 19 分（討論終了）となります。発表時間枠が固定されていますので, 発表者拈よび座長は発 表時間を厳守して下さい.

液晶プロジェクターの使用者は, Windows 版の PowerPoint 2013 で正常に表示されることを確認したファ イルを, USB フラッシュメモリー（Windows で読み込める形式）に保存して御持参下さい. 午前, 午後の最 初のセッション開始の 30 分前までに，会場の演壇まで上記メディアを持参し担当者に渡して下さい.

\section{9. ポスター発表について}

ポスター発表は，3 月 28 日（火） 10 時〜 17 時と 29 日（水） 9 時〜 15 時に，ポスター会場（3B棟 2 階）で 行います，発表者による説明・討論は 3 月 28 日（火）および 29 日（水）の 12 時〜 12 時 30 分に行われます ので, 多くの会員の参加を希望します。発表者は少なくとも20 分間は各自のポスター前で, 質疑・討論に対応 して下さい。説明・討論時間は上記時間内でなるべく長く取ることを希望します。

ポスター発表者は, 3 月 28 日（火）10 時までに, ポスター会場の指定された場所にポスターを掲示して下さ い. ポスターのサイズは最大で幅 $90 \mathrm{~cm} \times$ 高さ $180 \mathrm{~cm}$ が1枚です．揭示方法は会場係の指示に従って下さい. 掲示に必要な画鋲類は, 用意しております。展示物は 3 月 29 日（水） 15 時から 16 時の間に各自の責任で片付 けて下さい，29日（火）16 時の時点で片付けられていないポスター等は，大会実行委員会にて処分します。

\section{0. 出張依頼状・発表要旨集について}

（1）出張依頼状の必要な方は, 1. 出張期間 2. 依頼状提出先 3. 依頼状送付（返信）先を明記し，切手を 貼付した返信用封筒を同封の上，学会事務局へ抒申し込み下さい.

（2）定期購読をされている方で, 発表要旨集が 3 月 21 日（火）までに未着の場合は, 学会事務局へお申し出 下さい.

\section{1. 地理教育公開講座委員会主催第 31 回地理教育公開講座}

日時：3月 28 日 (火) 13 時 $~ 16$ 時

会場：第 0 会場

テーマ：「地理総合」(仮）とGIS（地理情報システム）

共催：日本地理教育学会

井田仁康（筑波大）：「地理総合」の方向性と GIS の可能性

田部俊充（日本女子大）・高阪宏行（日本大）：大学に掠ける GIS 研究から中等教育での活用を考光る

佐藤崇徳（沼津工業高専）：地理教育のための GIS 教材の開発

コメンテーター：國原幸一朗（名古屋学院大），小林岳人（千葉県立千葉高）

問合せ先：田部俊充 日本女子大学人間社会学部 † 214-8565 川崎市多摩区西生田 1-1-1

e-mail: tabe@fc.jwu.ac.jp

\section{GIS 講習会}

GIS 講習会（1）「地理必修化に向けた GIS 教材作成講座」

日時：3月28日（火） 16:15 17:45

会場：筑波大キャンパス内の PC 教室

内容：無料のオンライン GIS と公開データを用いた地理教材作成を体験する. 
GIS 講習会（2）「デスクトップ GIS 体験セミナー」

日時：3月30日（木） 10:00 12:00

会場：筑波大キャンパス内の PC 教室

内容：デスクトップGIS の基礎を体験する.

GIS 講習会（3）「エクセルとスマートフォンでできるフィールド調査」

日時：3月30日（木） 13:30 15:30

会場：筑波大キャンパス内の PC 教室及び屋外

内容：エクセルで設計した調査シートをスマートフォンでフィールドへ持ち出してデータ収集を行い，そ の結果をデスクトップ GIS で取り扱うまでの作業を体験する。

申し込みについては学会ホームページを御覧下さい.

\section{3. 地域調査士, GIS 学術士相談室の開設について}

資格専門委員会では地域調査士，GIS 学術士制度相談室を開設します，科目認定申請に関わる大学関係者対 象の事前相談の場として御活用下さい.

日時：3月 28 日（火) 13 時〜 17 時

場所：3B401 (3B棟 4 階)

\section{4. 無線 LAN 利用について}

会場では eduroamによる無線 LAN 接続を利用できます，前もって御所属の機関で eduroam のアカウント とパスワードを取得しておいて下さい.

\section{5. 学内での喫煙について}

所定の喫煙スペースを御利用下さい. 詳しくは会場係に抒尋ね下さい.

\section{6. 大会 役員}

\section{大会実行委員長：山下清海}

大会実行委員：池田 敦, 井田仁康, 市川康夫, 植田宏昭, 小口千明, 恩田裕一, 日下博幸, 呉羽正昭, 杉田倫明, 田中 博, 堤 純, 中西僚太郎, 八反地 剛, 松井圭介, 松岡憲知, 村山祐司, 森本健弘, 山下亜紀郎，山中 勤，湯澤規子 
第1日目 3月28日（火）午前

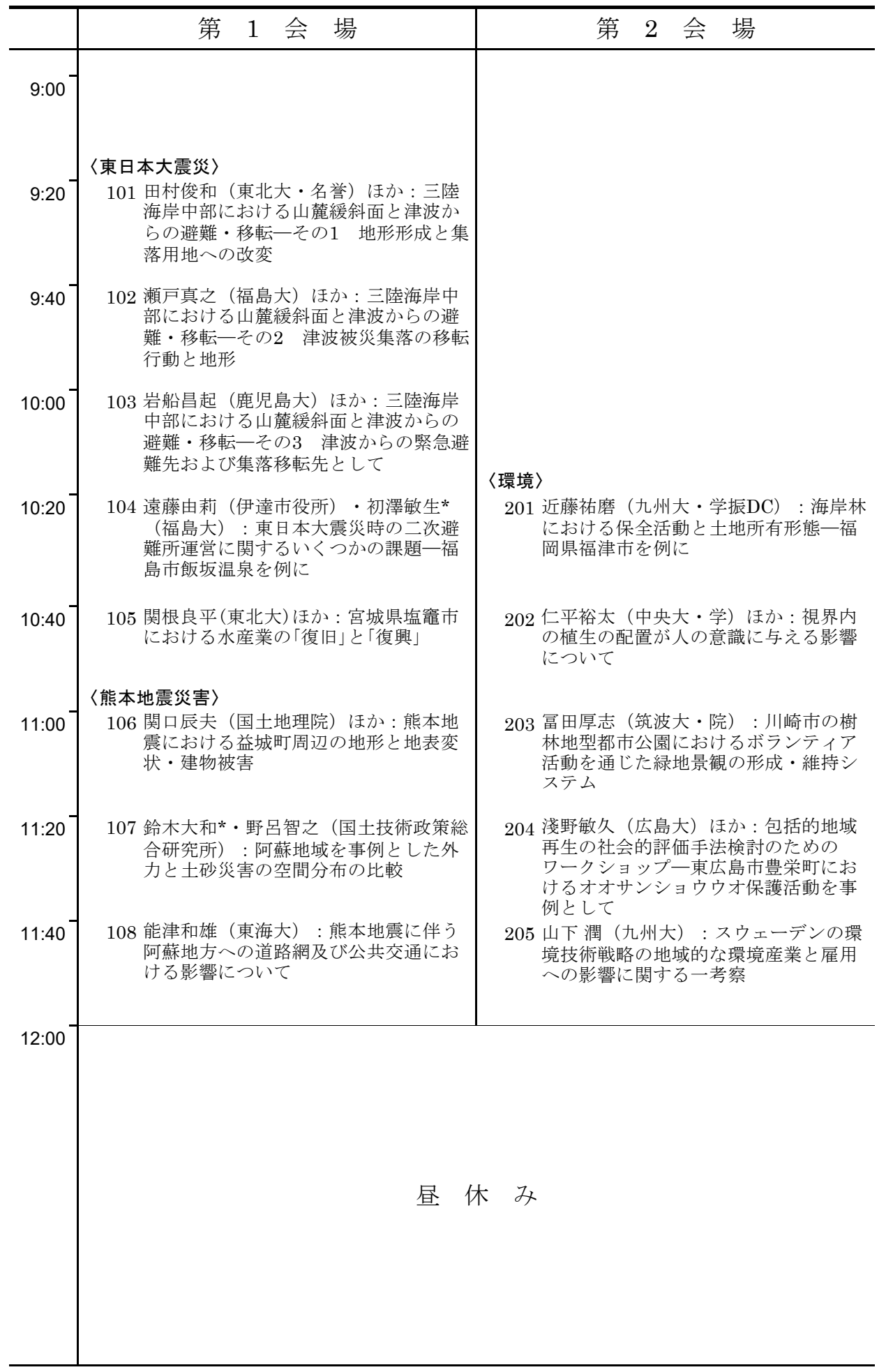




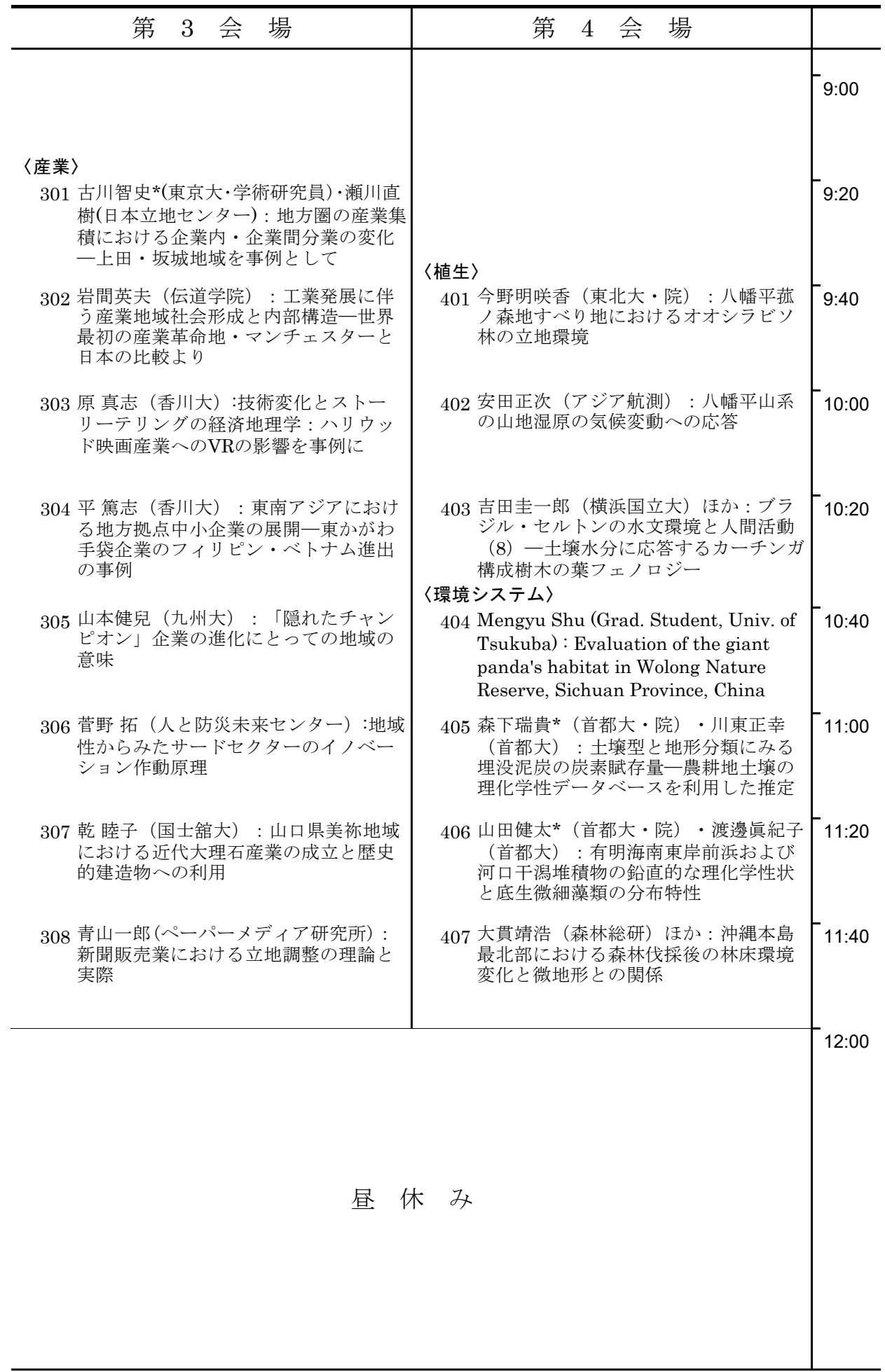


第1日目 3月28日（火）午前

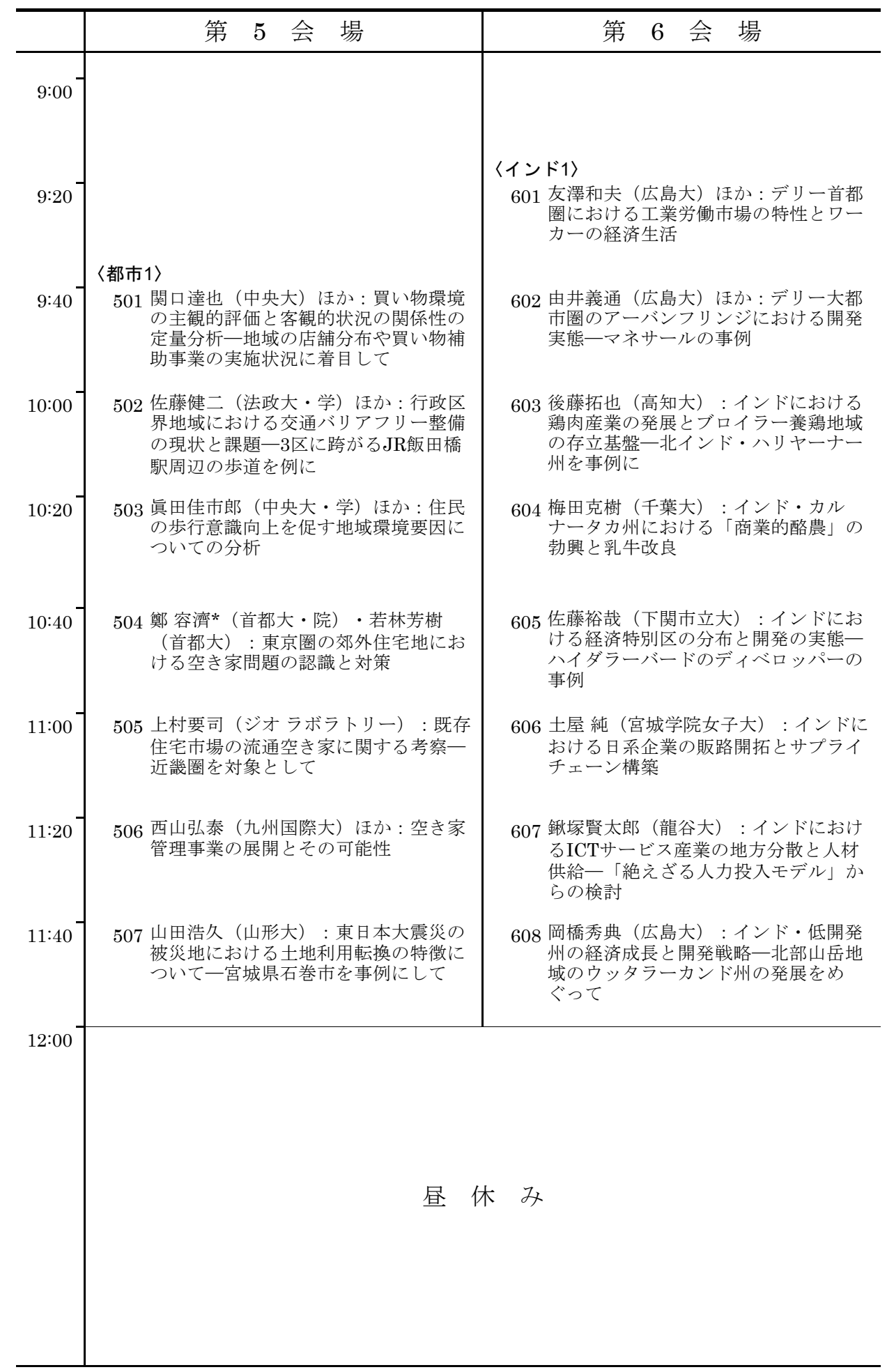


第1日目 3月28日（火）午前

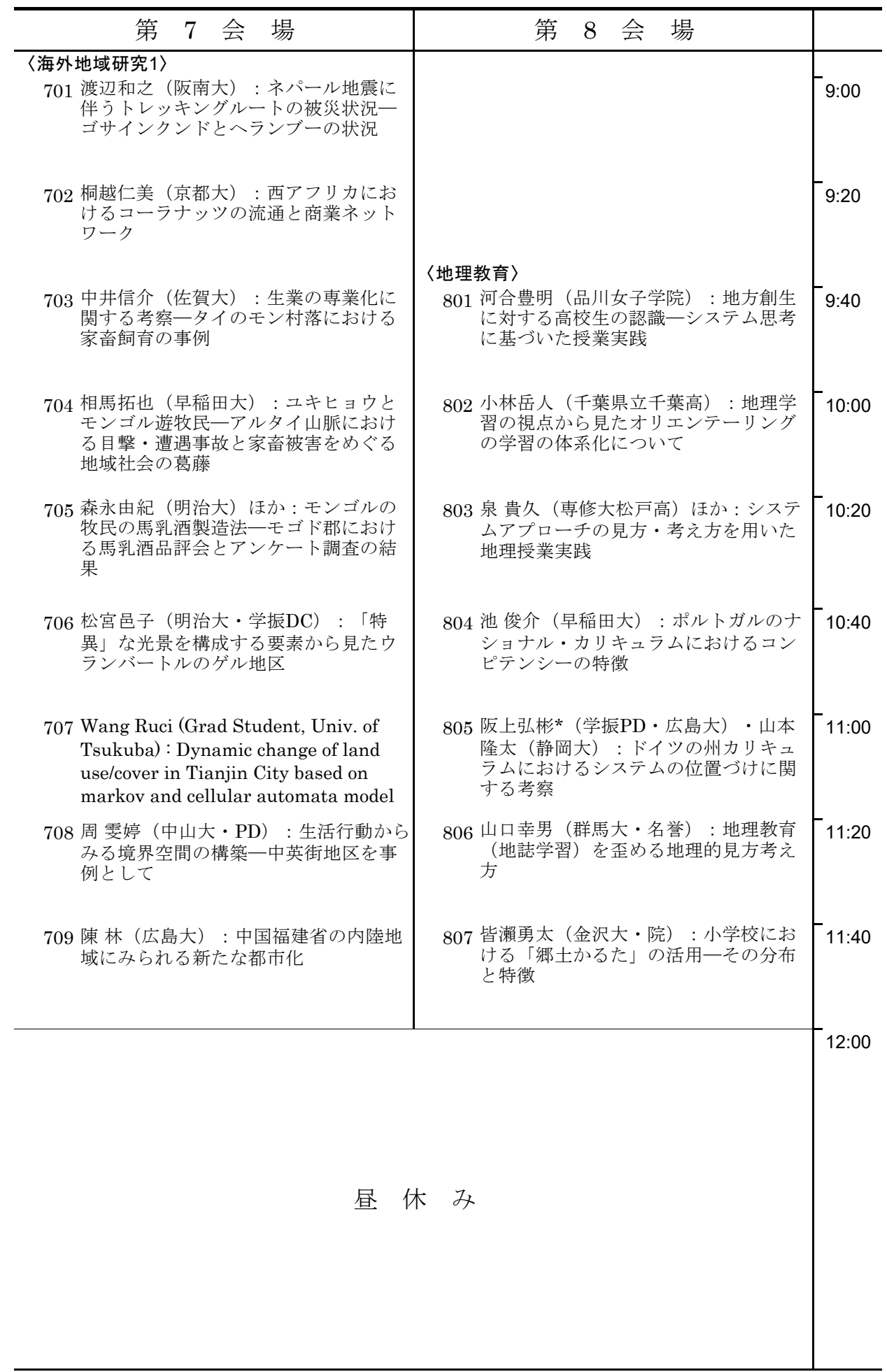


第1日目 3月28日（火）午前

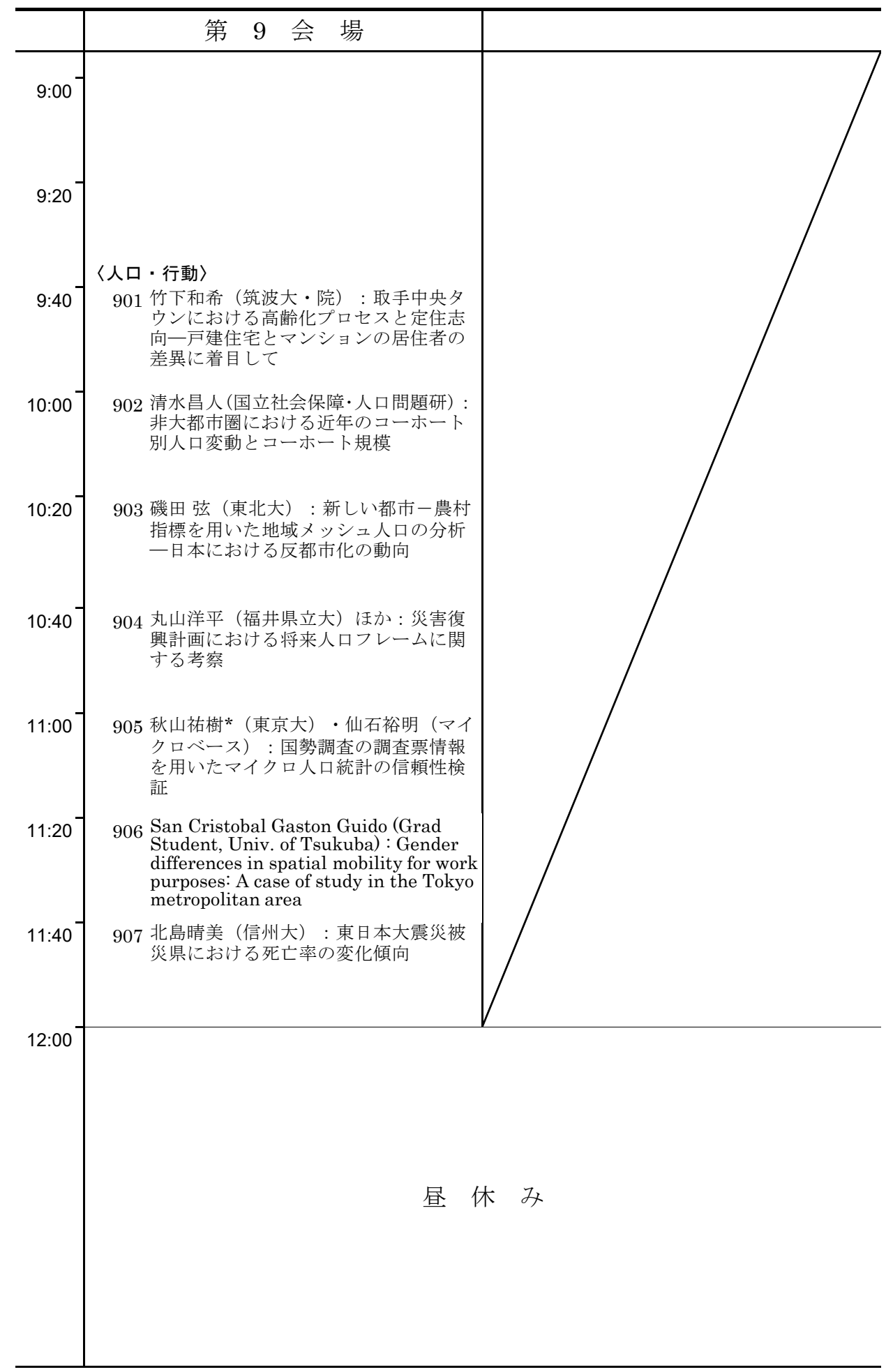


第1日目 3月28日（火）午後

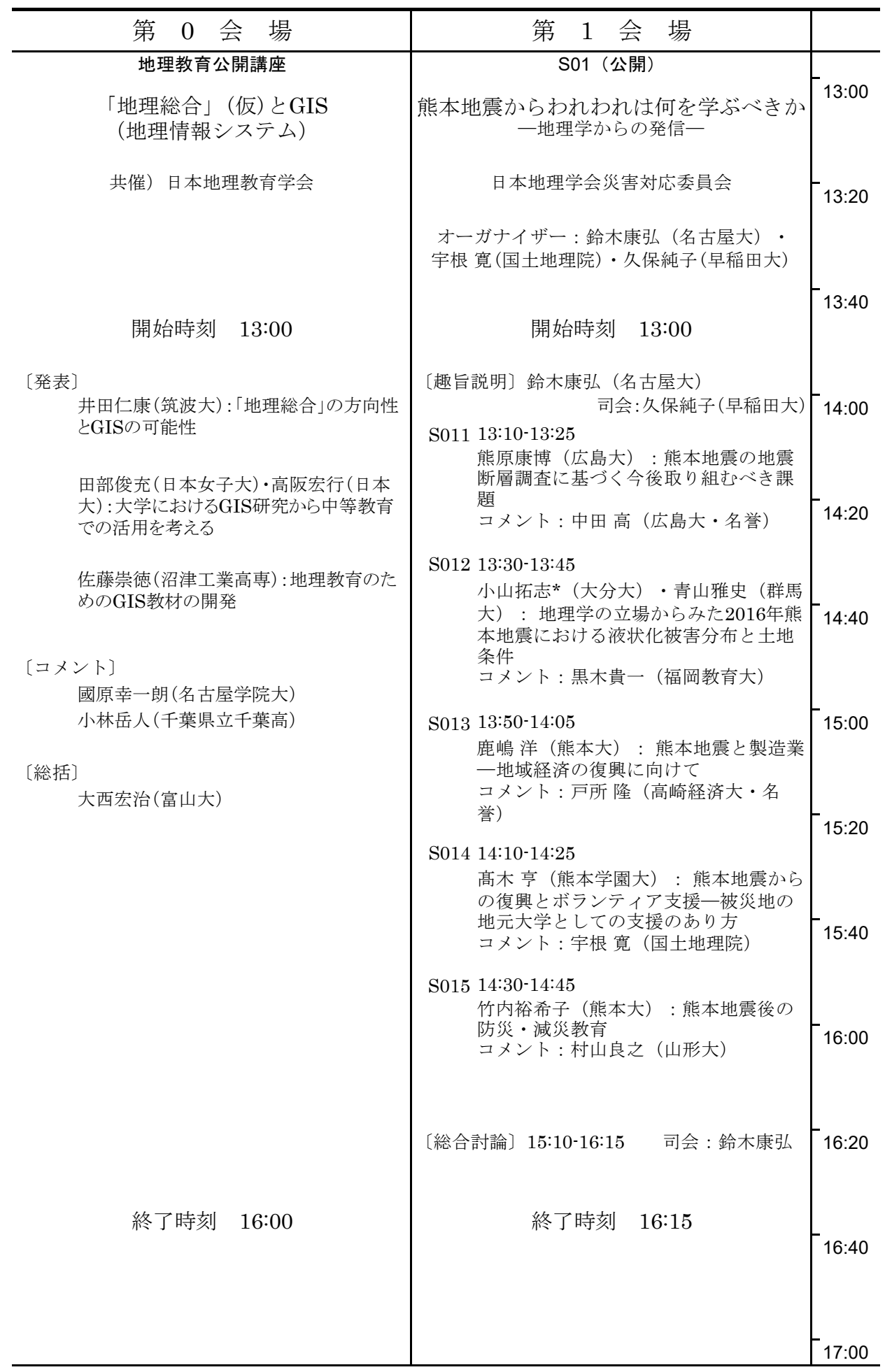


第1日目 3月28日（火）午後

\begin{tabular}{|c|c|c|}
\hline & 第 2 会 場 & 第 3 会 \\
\hline & S02 (公開) & S03 (公開) \\
\hline 13:00 & $\begin{array}{c}\text { 自然環境の保全と活用に関する } \\
\text { 国際的制度の諸相 }\end{array}$ & $\begin{array}{c}\text { 地名標淮化の現状と課題 } \\
\text { 一地名委員会 (仮称) の設置に向けて一 }\end{array}$ \\
\hline $13: 20$ & 日本地理学会ジオパーク対応委員会 & $\begin{array}{c}\text { 日本地理学会理事会· } \\
\text { 日本学術会議地球惑星科学委員会IGU分科会 }\end{array}$ \\
\hline & $\begin{array}{c}\text { オーガナイザー: 目代邦康(日本ジオサービス) } \\
\text { 有馬貴之 (帝京大)・河本大地(奈良教育大) }\end{array}$ & $\begin{array}{c}\text { オーガナイザー：岡本耕平（名古屋大） } \\
\text { 高木彰彦 (九州大) }\end{array}$ \\
\hline 13:40 & 開始時刻 $13: 00$ & 開始時刻 $13: 00$ \\
\hline 14:00 & $\begin{array}{l}\text { 座長 : 有馬貴之（帝京大） } \\
\text { S021 13:00-13:20 } \\
\text { 目代邦康（日本ジオサービス）：自然 } \\
\text { 環境の全と活用に関する国際的制度 } \\
\text { の諸相 (趣旨説明) }\end{array}$ & $\begin{array}{l}\text { S031 13:00-13:05 } \\
\text { 高木彰彦 (九州大) : 地名標準化の現 } \\
\text { 状と課題一地名委員会 (仮称) の設置 } \\
\text { に向けて (趣旨説明) }\end{array}$ \\
\hline $14: 20$ & $\begin{array}{l}\text { S022 13:20-14:00 } \\
\text { 吉田正人 (筑波大) : 世界遺産と生物 } \\
\text { 圈保存地域との連携の可能性 }\end{array}$ & $\begin{array}{l}\text { 座長 : 高木彰彦（九州大） } \\
\text { S032 13:05-13:25 } \\
\text { 森田 喬 (法政大) : 国際地図学協会 } \\
\text { (ICA）における地名についての動向 }\end{array}$ \\
\hline 14:40 & $\begin{array}{l}\text { S023 14:00-14:20 } \\
\text { 渡辺真人 (産総研) : ユネスコプログ } \\
\text { ラム化後のジオパークの状況 }\end{array}$ & $\begin{array}{l}\text { S033 13:25-13:45 } \\
\text { 渡辺浩平（帝京大）：国連地名標準化 } \\
\text { 会議の動向 }\end{array}$ \\
\hline 15:00 & $\begin{array}{l}\text { S024 14:20-14:40 } \\
\text { 若松伸彦(横浜国立大) : 早本におけ } \\
\text { るコネスコエ } \\
\text { 域) の現状と問題点 }\end{array}$ & $\begin{array}{l}\text { S034 } 13: 45-14: 05 \\
\text { 水田良 (国土地理院) : 国土地理院 } \\
\text { の地名に関する取り組み } \\
\text { S035 14:05-14:25 }\end{array}$ \\
\hline $15: 20$ & $\begin{array}{l}\text { 座長 : 河本大地（奈良教育大） } \\
\text { S025 14:40-15:00 } \\
\text { 淺野敏久 (広島大)：受け入れ地域か } \\
\text { らみたラム条約の「ワイズュー } \\
\text { ス」 }\end{array}$ & $\begin{array}{l}\text { 本田智比古 (帝国書院) : 教科書にお } \\
\text { ける地名表記に対する取り組みと課題 } \\
\text { S036 14:25-14:45 } \\
\text { 田邊裕 (環太平洋大) : 「地名委員 } \\
\text { 会」提案の趣旨 }\end{array}$ \\
\hline $15: 40$ & $\begin{array}{l}\text { S027 15:10-15:40 } \\
\text { 田中俊徳（東京大）：国際的な自然保 } \\
\text { 護制度の比較 }\end{array}$ & $\begin{array}{l}\text { 〔総合討論〕 15:00- } 15: 55 \\
\text { 座長 : 岡本耕平・高木彰彦 }\end{array}$ \\
\hline 16:00 & $\begin{array}{l}\text { 〔総合討論〕 15:40-17:00 } \\
\quad \text { 座長 : 目代邦康・有馬貴之・河本大地 }\end{array}$ & 終了時刻 16:00 \\
\hline $16: 20$ & 終了時刻 & \\
\hline $16: 40$ & & \\
\hline $17: 00$ & & \\
\hline
\end{tabular}


第1日目 3 月 28日（火）午後

\begin{tabular}{|c|c|c|}
\hline 第 4 会 場 & 第 5 会 & \\
\hline $\begin{array}{l}\text { 〈地形〉 } \\
411 \text { 水野一晴（京都大）：ケニア山とキリ } \\
\text { マンジャロの近年の自然環境の変化 }\end{array}$ & $\begin{array}{l}\text { 〈農業・農村〉 } \\
511 \text { 松尾忠直 (立正大) : 企業による農業 } \\
\text { の展開—モヤシ生産の事例 }\end{array}$ & $13: 00$ \\
\hline $\begin{array}{l}412 \text { 山縣耕太郎 (上越教育大)：ケニア山， } \\
\text { Tyndall水河前面における土畩発達過程 }\end{array}$ & $\begin{array}{l}512 \text { 岡田 登（鹿児島県立短大）：鹿児島県 } \\
\text { 指宿市における農業法人設立と野菜産 } \\
\text { 地の変容 }\end{array}$ & $13: 20$ \\
\hline $\begin{array}{l}413 \text { 大谷侑也 }(\text { 京都大・院）：ケニア山に } \\
\text { おけ永河縮小と水環境の変化が地域 } \\
\text { 住民に与える影響 }\end{array}$ & 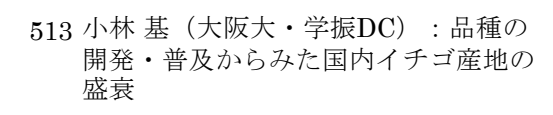 & $13: 40$ \\
\hline $\begin{array}{c}414 \text { 山本遼平 (新潟大・院) ・奈良間千之** } \\
\text { (新潟大) ほか: 北アルプスの水河・ } \\
\text { 越年性雪渓の年間質量収支と環境条件 }\end{array}$ & $\begin{array}{l}514 \text { シュレーガ ベンジャミン(ハワイ大・ } \\
\text { 院): : 日常食生活の地理学的アプローチ } \\
\text { 一日本の鶏肉を実例として }\end{array}$ & $14: 00$ \\
\hline $\begin{array}{l}415 \text { 畠瞳美（新潟大・院）ほか : 北アルプ } \\
\text { 到白馬大雪溪における落石分布と地 } \\
\text { 形変化 }\end{array}$ & $\begin{array}{l}515 \text { 飯塚 遼*（秀明大）・菊地俊夫（首都 } \\
\text { 大) : 東京都における都市農業の立地 } \\
\text { 形態の変容 }\end{array}$ & $14: 20$ \\
\hline 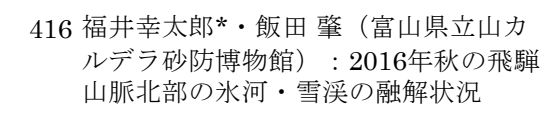 & $\begin{array}{l}516 \text { 淡野寧彦（愛媛大）：肉は「うまい」 } \\
\text { のか, 「銘柄豚事業に } \\
\text { みられる差別化の特色と空間性の一考 } \\
\text { み察 }\end{array}$ & $14: 40$ \\
\hline $\begin{array}{l}417 \text { 今村友則* (筑波大・院) ・池田 敦 } \\
\text { （筑波大）：兰国山脈平標山の雪食裸 } \\
\text { 地における夏季の侵食プロセス }\end{array}$ & $\begin{array}{l}517 \text { 庄子 元* (宮城教育大) ・吕田国光 } \\
\text { (金沢大) : 都市近郊中山間地域にお } \\
\text { ける就業動向からみた農地利用の維持 } \\
\text { 基盤一石川県能美市涻集落を事例に }\end{array}$ & $15: 00$ \\
\hline 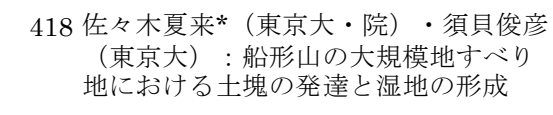 & 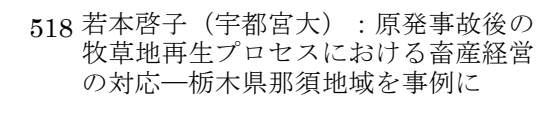 & $15: 20$ \\
\hline $\begin{array}{c}419 \text { 小林勇介* (北海道大・院) ・渡辺悌二 } \\
\text { (北海道大) : 青山北海平における } \\
\text { 登山道侵食の変化と将来予測 }\end{array}$ & 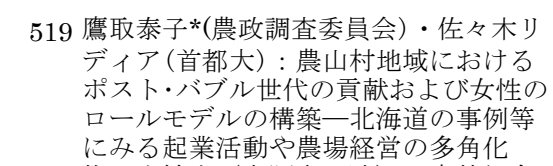 & $15: 40$ \\
\hline $\begin{array}{l}420 \text { 三浦英樹（極地研）ほか : 最終水期最 } \\
\text { 盛期のグリーンラン゙水床復元図の再 } \\
\text { 検討一隆起海浜地形地質とGIAモデル } \\
\text { の視点から }\end{array}$ & $\begin{array}{l}520 \text { 佐々木敏光（大阪大・院）：森林組合 } \\
\text { の合併動向と課題一和歌山県日高川町 } \\
\text { と有田川町を事例として }\end{array}$ & $16: 00$ \\
\hline \multirow[t]{3}{*}{$\begin{array}{l}421 \text { 小松原 玩（産総研）：湿潤変動帯の地 } \\
\text { 形学再び }\end{array}$} & $\begin{array}{l}521 \text { 遊佐 暁（筑波大・院）：霞ヶ浦におけ } \\
\text { る湖沼環境変化に伴う内水面漁業の構 } \\
\text { 造変容 }\end{array}$ & $16: 20$ \\
\hline & $\begin{array}{l}522 \text { 松井 歩 (名古屋大・院) : 複合的生業 } \\
\text { 形態と沿岸漁場の時空間的利用に関す } \\
\text { る研究 }\end{array}$ & $16: 40$ \\
\hline & & $17: 00$ \\
\hline
\end{tabular}


第1日目 3 月 28日（火）午後

\begin{tabular}{|c|c|c|}
\hline & 第 6 会 場 & 7 会 場 \\
\hline $13: 00$ & $\begin{array}{l}\text { 〈地域計画〉 } \\
611 \text { 竹中克行 (愛知県立大) : 政権交代に } \\
\text { よる都市計画マスタープランの方針転 } \\
\text { 換 ーレウス (カタルーニャ) の経験か } \\
\text { ら }\end{array}$ & $\begin{array}{l}\langle\mathrm{GIS \rangle} \\
711 \text { 木田仁廣*（首都大・院）・川東正幸 } \\
\text { (首都大) : 道路建設による土地機能 } \\
\text { 変化の面的推定 }\end{array}$ \\
\hline $13: 20$ & $\begin{array}{l}612 \text { 日野正輝（中国学園大）：用語「広域 } \\
\text { 中心都市」,「地中枢都市」, 「札仙 } \\
\text { 広福」の登場と定着 }\end{array}$ & $\begin{array}{l}712 \text { 堤田成政（京都大）：1982-2015年の全 } \\
\text { 球土地被覆の変遷 }\end{array}$ \\
\hline $13: 40^{-}$ & $\begin{array}{l}613 \text { 中山穂孝（大阪市立大・研）: 特別都 } \\
\text { 市建設法と広域交通ネットワークから } \\
\text { みた観光都市の発展一静岡県熱海市を } \\
\text { 事例に }\end{array}$ & $\begin{array}{l}713 \text { スプレイグ デイビッド（農業・食品産 } \\
\text { 業技術総合研究機構）：地図情報から } \\
\text { 作成する「谷津田」のGISデータベー } \\
\text { ス }\end{array}$ \\
\hline $14: 00^{-}$ & $\begin{array}{l}614 \text { 石原 肇（大阪産業大）：バルイベント } \\
\text { の実施範囲と中心市街地活性化基本計 } \\
\text { 画の区域設定との整合性一近畿 } 2 \text { 府 } 4 \text { 県 } \\
\text { を事例として }\end{array}$ & $\begin{array}{c}714 \text { 有賀夏希（東京地図研究社）ほか : 歩 } \\
\text { 道ネットワークDBを活用したタブレッ } \\
\text { ト端末用アプリケーションの開発 }\end{array}$ \\
\hline $14: 20^{-}$ & $\begin{array}{l}615 \text { 畠山輝雄（鳴門教育大）：京都市美術 } \\
\text { 館への林ングライツの導入と合意 } \\
\text { 形成 }\end{array}$ & $\begin{array}{l}715 \text { 矢野桂司*（立命館大）・鎌田 遼（フ } \\
\text { リーランス・プログラマー）: オープ } \\
\text { ンプラットフォームによる日本の古地 } \\
\text { 図オンラインの構築 }\end{array}$ \\
\hline $14: 40^{-}$ & 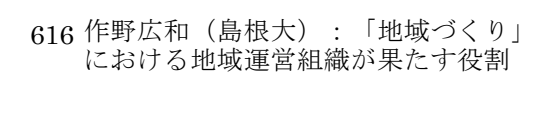 & $\begin{array}{l}716 \text { 原 雄一（京都学園大）ほか：日本列島 } \\
\text { 縦断歴史街道のルート設定とクラウド } \\
\quad \text { 化 }\end{array}$ \\
\hline & 〈コミュニティ〉 & \\
\hline $15: 00^{-}$ & $\begin{array}{l}617 \text { 馬㴊 泰（高知工科大）：高知県梼原町 } \\
\text { を対象とした高齢者の “生きがい感” } \\
\text { の特徵分析 }\end{array}$ & $\begin{array}{l}717 \text { 湯田ミノリ（福岡女子大）: EpiCollect+ } \\
\text { を用いたスマートフォンによる野外調 } \\
\text { 查の実践 }\end{array}$ \\
\hline $15: 20^{-}$ & $\begin{array}{l}618 \text { 櫛引素夫（青森大）ほか：青森市・幸 } \\
\text { 畑団地における転入者の実態調査試行 } \\
\text { 一住民との協働に基づく大学の教育・ } \\
\text { 地域貢献活動 }\end{array}$ & $\begin{array}{c}718 \text { 伊藤 悟（金沢大）ほか：地理教育用 } \mathrm{AR} \\
\text { （拡張現実）情報システム（6）一新た } \\
\text { なシステムの活用とその特徵 }\end{array}$ \\
\hline $15: 40^{-}$ & $\begin{array}{c}619 \text { 久 隆浩（近畿大）：地域における交流 } \\
\text { の場の意義と効果に関する研究一北千 } \\
\text { 里地域交流会を事例として }\end{array}$ & $\begin{array}{l}719 \text { 秋本弘章（獨協大）ほか：地理教育用 } \\
\mathrm{AR} \text { (拡張現実) システム（7）—高等 } \\
\text { 学校におけるうィールドワーク教材の } \\
\text { 開発と実践 }\end{array}$ \\
\hline $16: 00^{-}$ & $\begin{aligned} & 620 \text { 中山英光（熊本大・院）：旧炭住コ } \\
& \text { ミュニティの維持と炭鉱離職者のライ } \\
& \text { フヒストリー一福岡県嘉麻市銭代坊地 } \\
& \text { 区を事例としてて }\end{aligned}$ & $\begin{array}{c}720 \text { 山内啓之（東京大）ほか：GISの実習 } \\
\text { 用オープン教材の試験運用と改良 }\end{array}$ \\
\hline $16: 20^{-}$ & $\begin{array}{l}621 \text { 小田宏信（成蹊大）・遠藤貴美子* (敬 } \\
\text { 愛大) ほか：サライト誘致 } \\
\text { による集落再生事業の実際一徳島県海 } \\
\text { 部郡美波町の場合 }\end{array}$ & $\begin{array}{l}721 \text { 谷謙二（埼玉大）：新しくなった地理 } \\
\text { 情報分析支援システム「MANDARA10」 } \\
\text { の特徵 }\end{array}$ \\
\hline $16: 40$ & 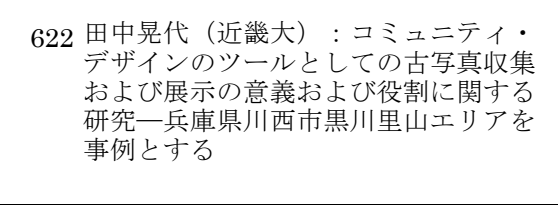 & \\
\hline
\end{tabular}


第1日目 3月28日（火）午後

\begin{tabular}{|c|c|c|}
\hline 第 8 会 場 & 第 9 会 場 & \\
\hline 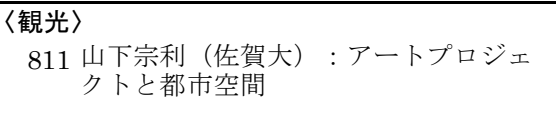 & $\begin{array}{l}\text { 〈歴史・文化〉 } \\
911 \text { 島倉聖朗（横浜市立大・院）：大正期 } \\
\text { にお3ける太平洋航路の「船の楽士」と } \\
\text { ジャズの輸入 }\end{array}$ & 13:00 \\
\hline $\begin{array}{l}812 \text { 和田 崇（県立広島大）：「映画のまち· } \\
\text { 尾道」の認知度と観光行動 }\end{array}$ & 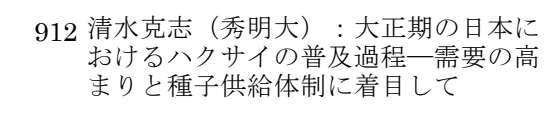 & {$[13: 20$} \\
\hline $\begin{array}{l}813 \text { 杉本興運（首都大）：イベント開催時 } \\
\text { に执る観光者の地域内移動パターン } \\
\text { 一東京・上野地域の゙゙フェステバル } \\
\text { を事例に }\end{array}$ & $\begin{array}{l}913 \text { 鈴木 允（横浜国立大）：大正期におけ } \\
\text { る山村地域からの人移動一愛知県賀 } \\
\text { 茂村居所寄留届の分析から }\end{array}$ & {$[13: 40$} \\
\hline 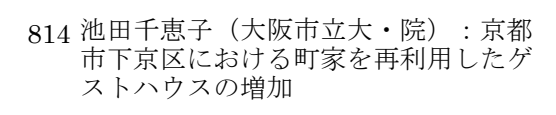 & 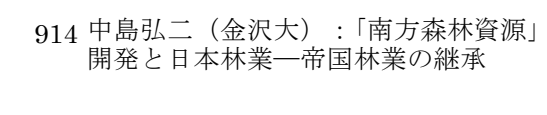 & $14: 00$ \\
\hline 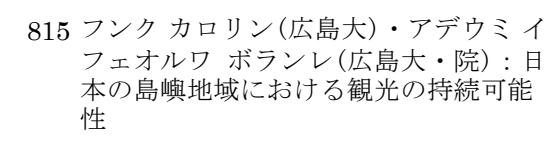 & $\begin{array}{l}915 \text { 谷端 郷（立命館大）：昭和戦前期にお } \\
\text { ける水害の地域的特徴一道府県別の水 } \\
\text { 害に関寸る統計の分析 }\end{array}$ & $14: 20$ \\
\hline $\begin{array}{l}816 \text { 佐久真沙也加（ハワイ大）：エコマイ } \\
\text { シドの構築—目本におけるエコツーリ } \\
\text { ズム政策の発展 }\end{array}$ & $\begin{array}{l}916 \text { 松本裕行（大阪市立大・院）：占領期 } \\
\text { 大阪における接収不動産についての調 } \\
\text { 查 }\end{array}$ & $14: 40$ \\
\hline 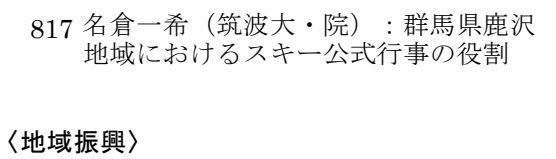 & 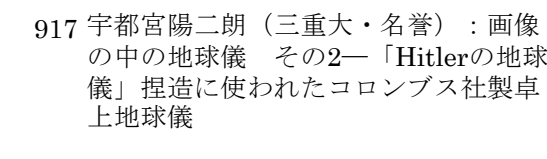 & 15:00 \\
\hline $\begin{array}{c}818 \text { 佐竹泰和（東京大・院）：山梨県にお } \\
\text { ける公衆無線LAN設置場所の空間特性 }\end{array}$ & $\begin{array}{l}918 \text { 西村和洋(滋賀県土地家屋調查士関す)： } \\
\text { 元禄八年作成の大津町絵四に関る } \\
\text { 考察 }\end{array}$ & $15: 20$ \\
\hline $\begin{array}{l}819 \text { 池田和子（首都大）：地域振興の取り } \\
\text { 組みと地域文化 }\end{array}$ & $\begin{array}{l}919 \text { 中村周作 (宮崎大)：佐賀県域におけ } \\
\text { る飲酒嗜好の地域的展開 }\end{array}$ & $15: 40$ \\
\hline $\begin{array}{c}820 \text { 遊佐順和（札幌国際大短期大学部）： } \\
\text { 地理的表示保護制度の活用による北海 } \\
\text { 道産昆布の付加価値向上 }\end{array}$ & 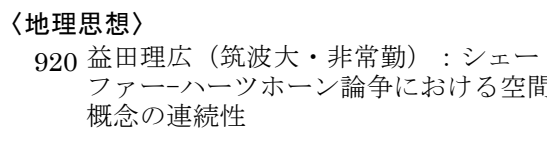 & 16:00 \\
\hline $\begin{array}{l}821 \text { 森 泰規（博報堂）：「地ブランド」検 } \\
\text { 討の参照点—「萩しーまーと」 }\end{array}$ & $\begin{array}{l}921 \text { 米家泰作 (京都大) : 近代日本におけ } \\
\text { る朝鮮地誌の出版とその系譜 }\end{array}$ & [16:20 \\
\hline $\begin{array}{c}822 \text { 平山弘 (阪南大) : ストーリー構築に } \\
\text { よる地域資源ブランドの開発と課題一 } \\
\text { 沖縄瑞泳酒造を中心に }\end{array}$ & $\begin{array}{l}922 \text { 渋谷鎮明（中部大）：現代韓国におけ } \\
\text { る風水地理思想の学術的評価一不動 } \\
\text { 産・都市研究分野を中心に }\end{array}$ & $16: 40$ \\
\hline & & {$[17: 00$} \\
\hline
\end{tabular}


第2日目 3月 29日（水）午前

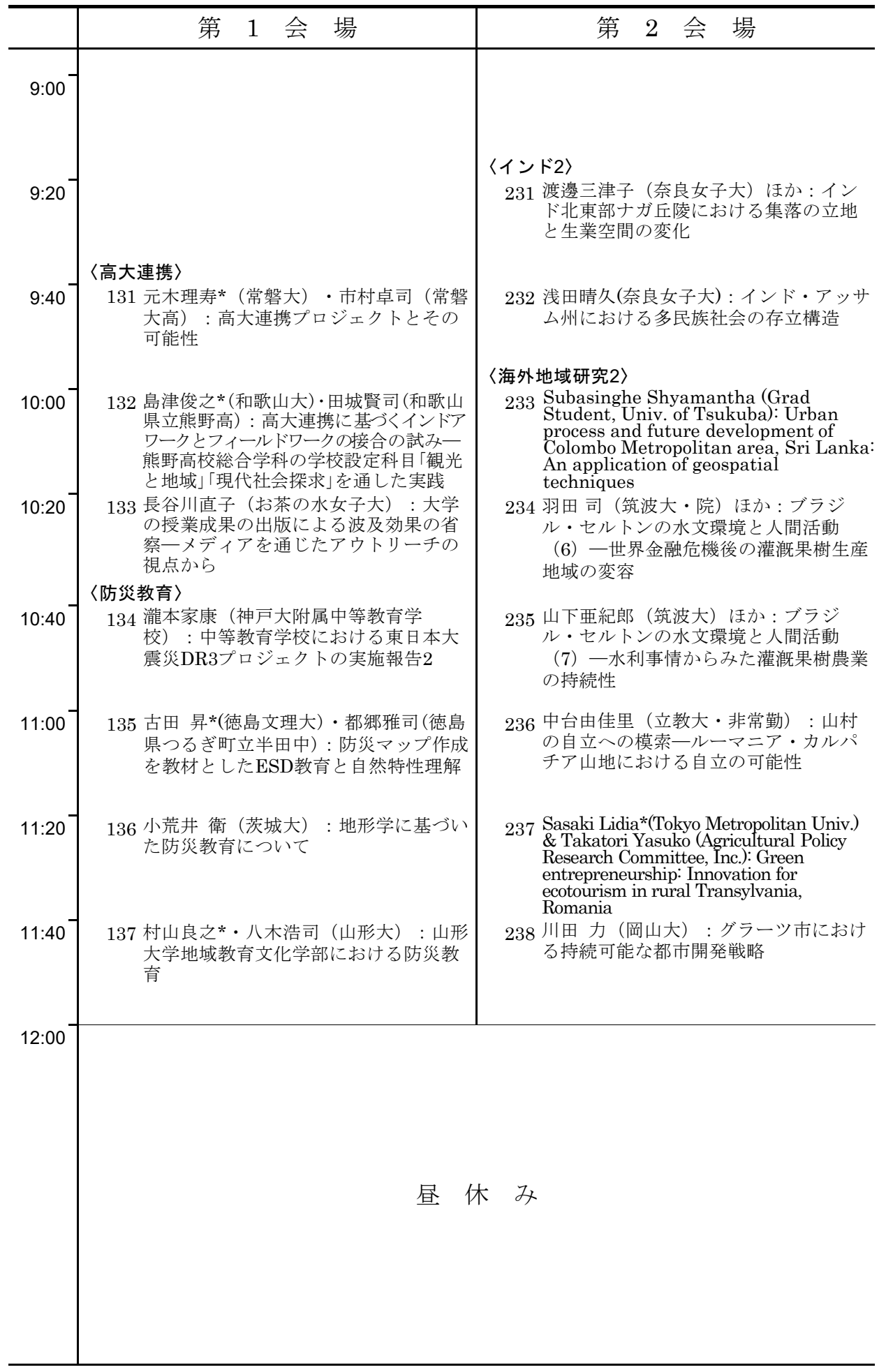


第2日目 3月 29日（水）午前

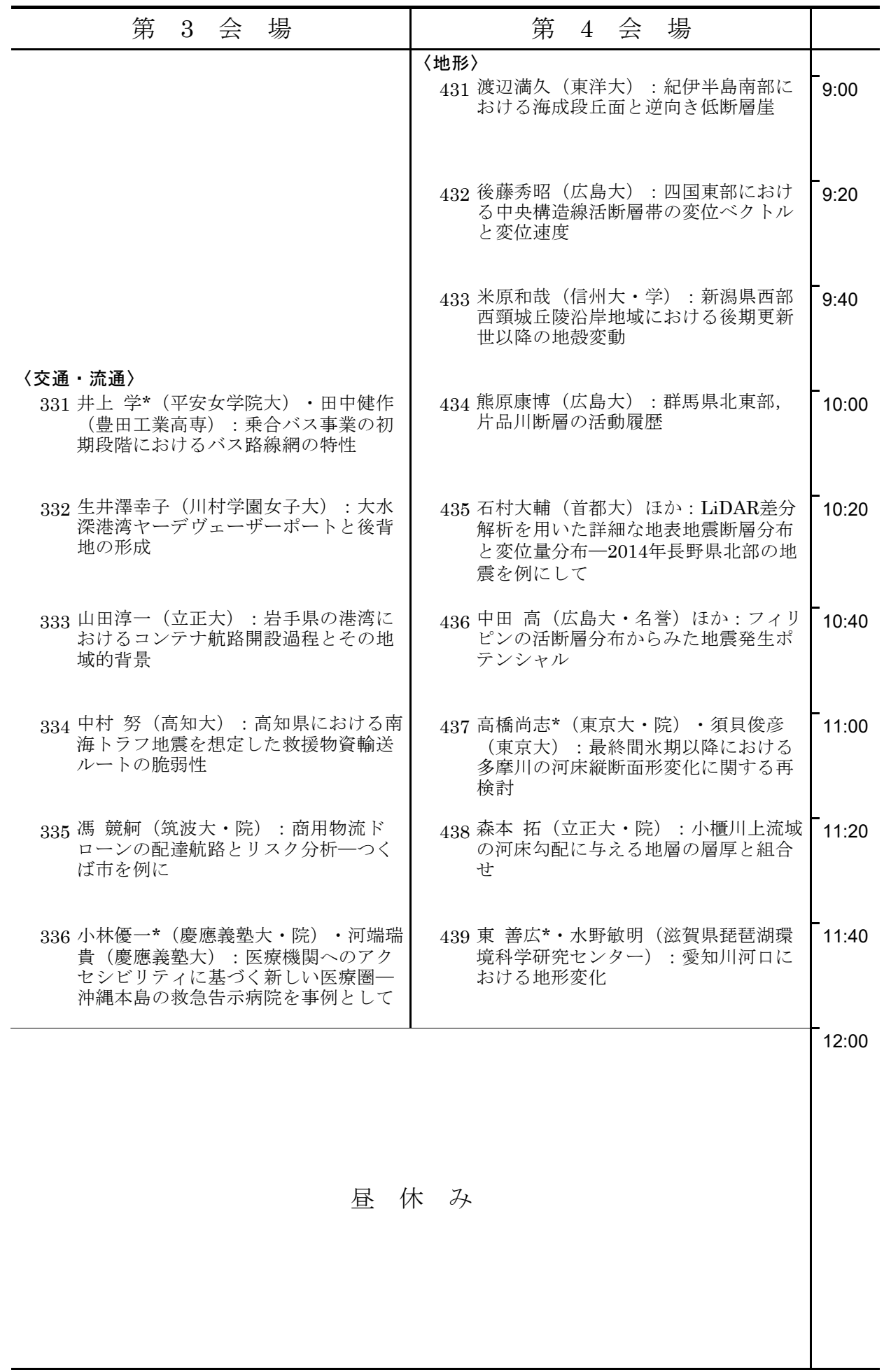


第2日目 3 月 29 日（水）午前

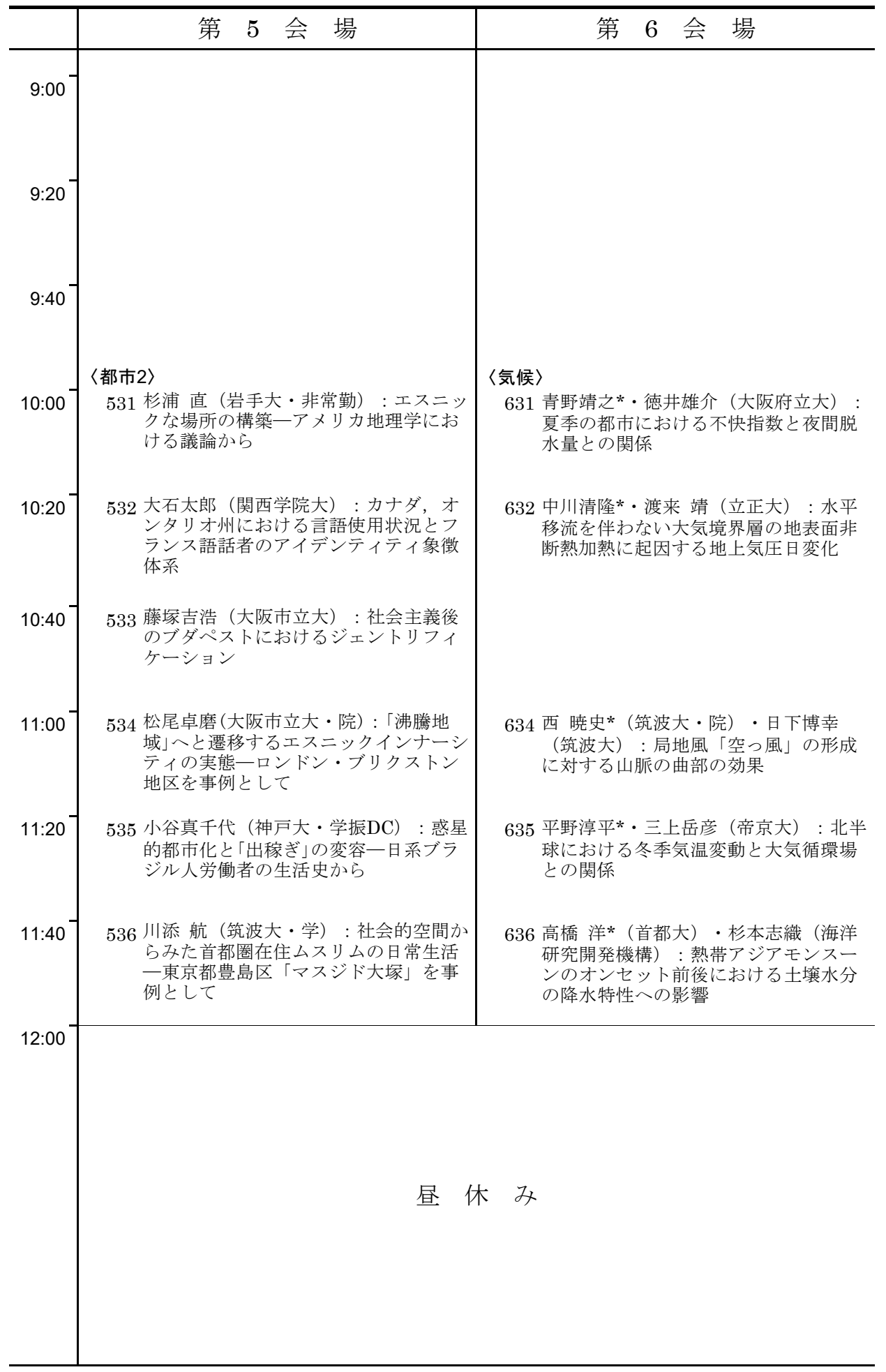


第2日目 3月29日（水）午前

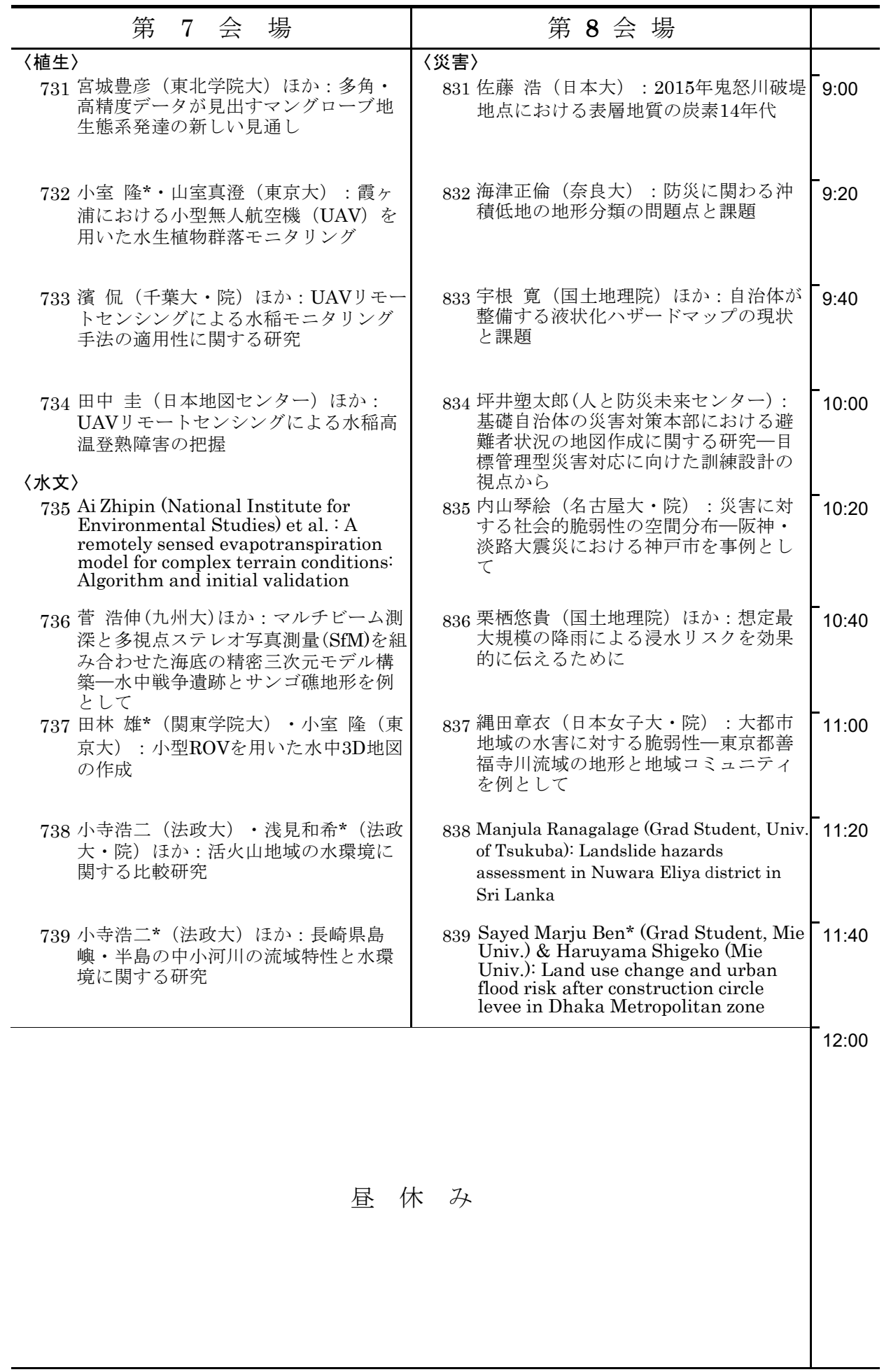


第2日目 3 月 29 日（水）午後

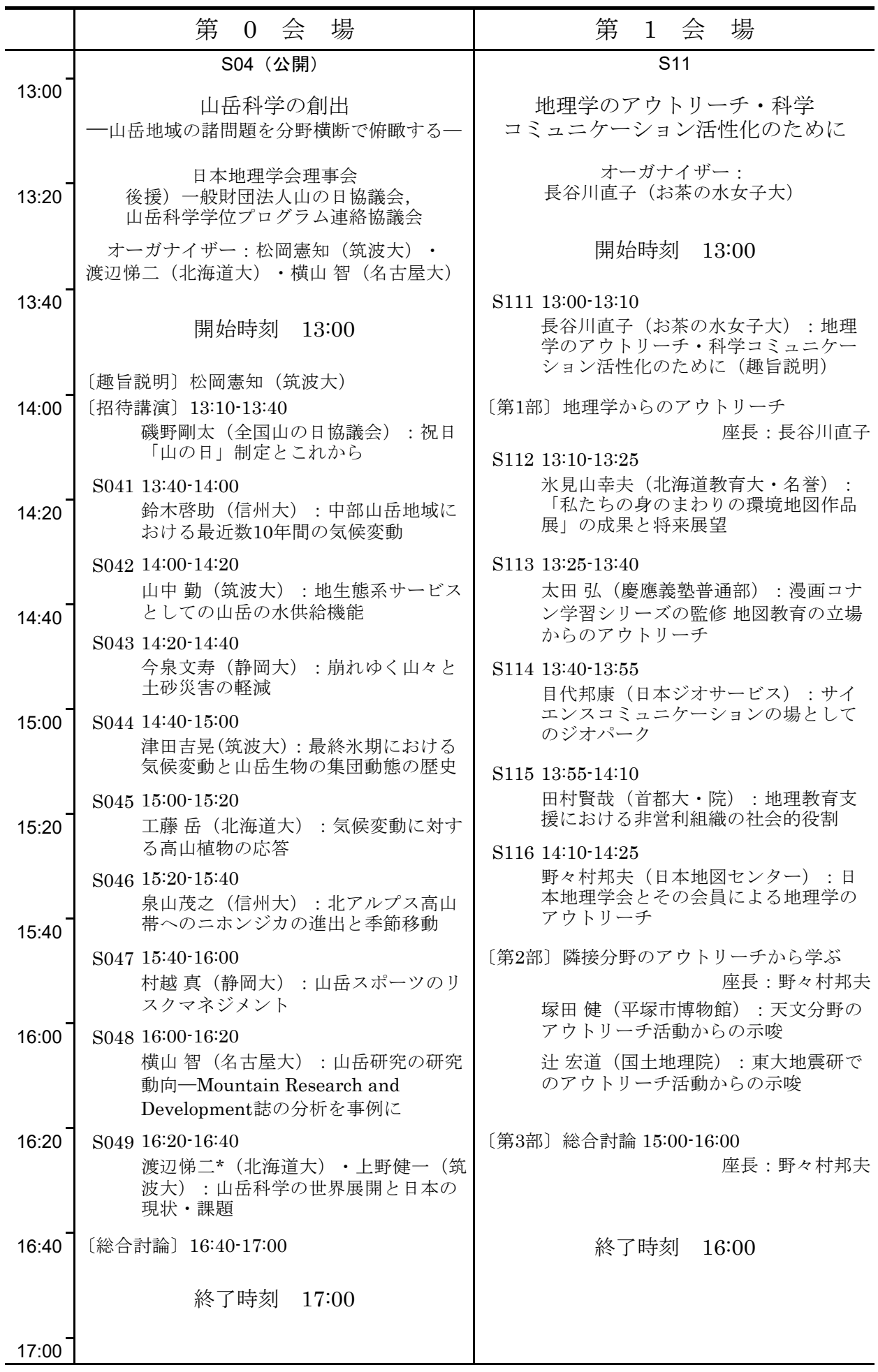




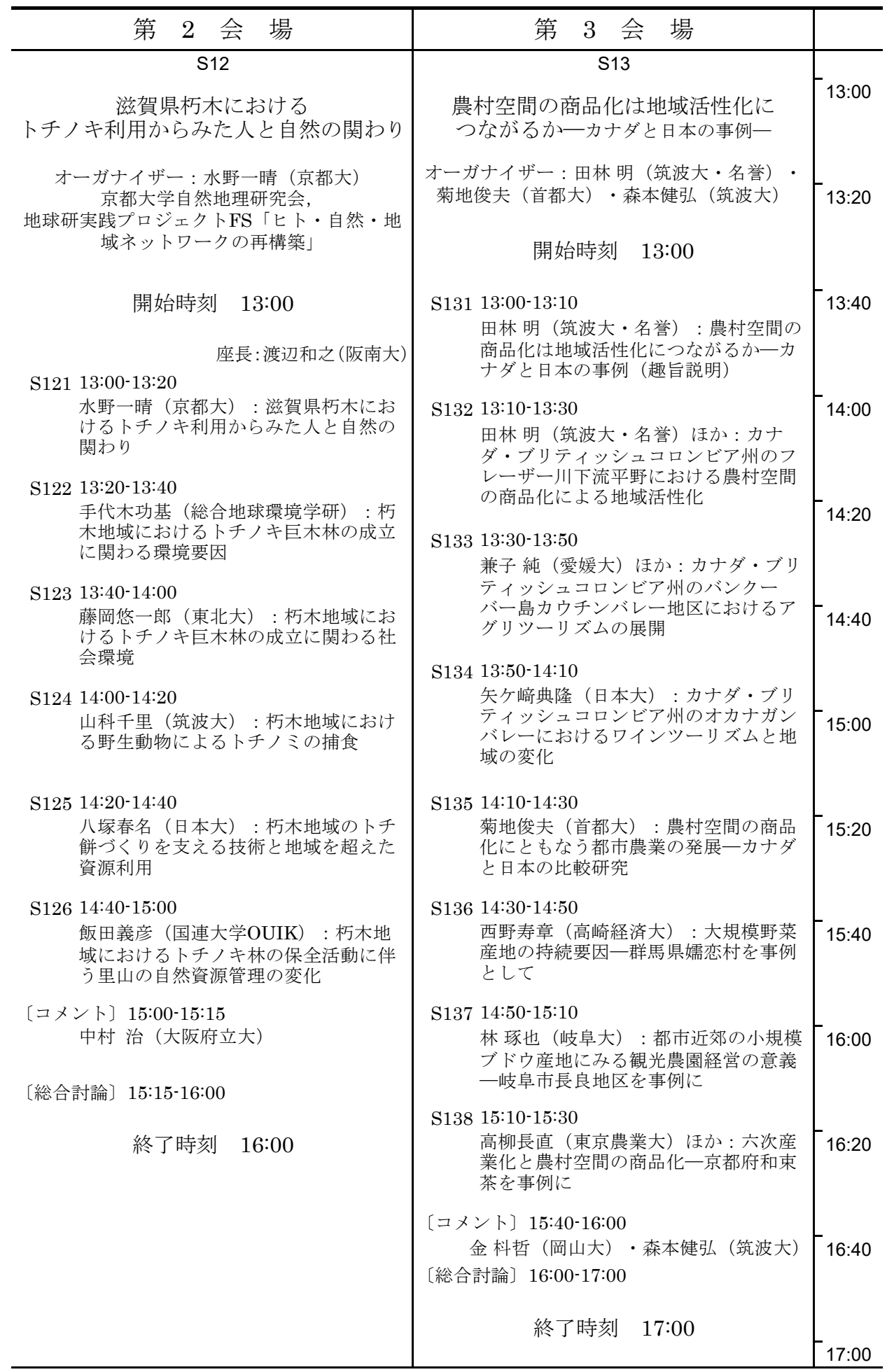


第2日目 3 月 29 日（水）午後

\begin{tabular}{|c|c|c|}
\hline & 第 4 会 場 & 会 \\
\hline 13:00 & $\begin{array}{c}\mathrm{S} 14 \\
\text { 黑潮の道 } \\
\text { 一地域学的比較研究をざして一 }\end{array}$ & $\begin{array}{l}\text { データレスキューによる } \\
\text { アジアの気候変動解明 }\end{array}$ \\
\hline $13: 20$ & $\begin{array}{c}\text { オーガナイザー : 野間晴雄 (関西大) } \\
\text { 小ロ千明（筑波大）・・村周（宮崎大） } \\
\text { 開始時刻 } \quad 13: 00\end{array}$ & 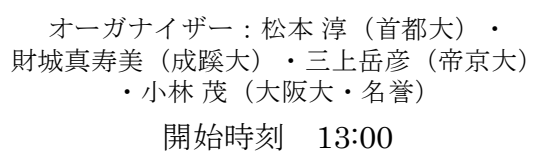 \\
\hline $13: 40$ & $\begin{array}{l}\text { 〔趣旨説明〕野間晴雄 } \\
\text { S141 } 13: 10-13: 30 \quad \text { 司会 : 中西僚太郎 } \\
\text { 水田義一(和歌山県立紀伊風土記の }\end{array}$ & $\begin{array}{l}\text { S151 13:00-13:05（趣旨説明） } \\
\text { 松本 淳（首都大）ほか: データレス } \\
\text { キューによるアジアの気候変動解明 }\end{array}$ \\
\hline $14: 00$ & $\begin{array}{l}\text { 兵) : 紀伊半島南端の国境変遷と画定一 } \\
\text { 熊野・紀伊・志摩・伊勢国 } \\
\text { S142 13:30-13:50 } \\
\text { 石坂澄子 (茨木市史編さん室) : 輸出 }\end{array}$ & $\begin{array}{l}\text { S152 13:05-13:25 座長 : 財城真寿美 } \\
\text { 久保田尚之 (東京大) ほかか:東アジアア } \\
\text { 東南アジアに拈るる気象データのデー } \\
\text { タレスキューについて }\end{array}$ \\
\hline $14: 20$ & $\begin{array}{l}\text { 入品としての寒天一貿易量の推移を中 } \\
\text { 心として }\end{array}$ & 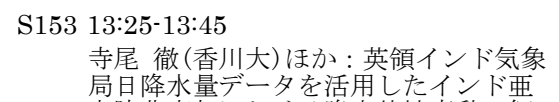 \\
\hline $14: 40^{-}$ & 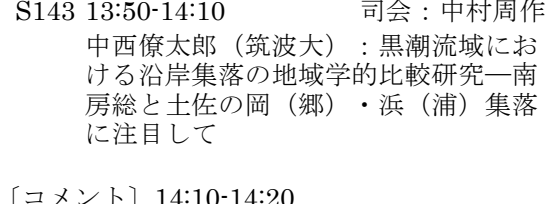 & $\begin{array}{l}\text { S154 13:45-14:05 } \\
\text { 藤部文昭（首都大）ほか: 気象庁の降 } \\
\text { 水量データのディジタル化一これまで } \\
\text { の経緯と問題点 }\end{array}$ \\
\hline $15: 00$ & $\begin{array}{l}\text { 三木一彦 (文教大) } \\
\text { 矢嶋 䉷 (神戸学院大) } \\
\text { [質疑応答] } 14: 20-14: 30\end{array}$ & $\begin{array}{l}\text { S155 14:05-14:25 } \\
\text { 山本晴彦 (山口大) : 帝国日本におけ } \\
\text { る気像観測ネットワークの構築一陸軍 }\end{array}$ \\
\hline $15: 20$ & 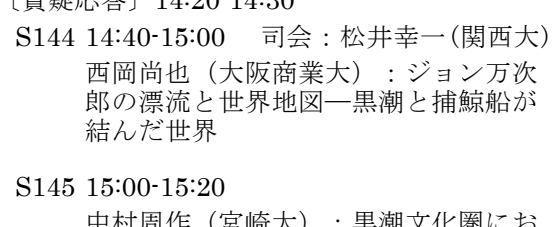 & $\begin{array}{l}\text { 気象部 } \\
\text { S156 14:25-14:45 } \\
\text { 小林茂 (大阪大・名誉) : 第二次世界 } \\
\text { 大戦期の東アジア・東南ア洋におけ } \\
\text { る日本軍・連合国軍の気像観測—デー } \\
\text { タレスキューの視点からら }\end{array}$ \\
\hline $15: 40$ & $\begin{array}{l}\text { 中村周作 (营崎大) : 黒潮文化圈にお } \\
\text { ける伝統的魚介類食の地域的展開一千 } \\
\text { 葉県, 高知県他を事例として }\end{array}$ & $\begin{array}{l}\text { S157 14:55-15:15 座長 : 赤坂郁美 (専修大) } \\
\text { 財城真寿美（成蹊大) ほか：日本にお }\end{array}$ \\
\hline 16:00 & 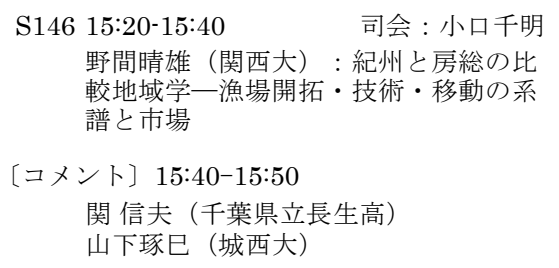 & 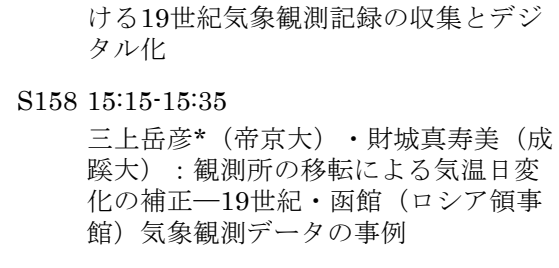 \\
\hline $16 \cdot 40$ & $\begin{array}{l}\text { 〔質疑応答〕15:50-16:00 司会 : 小口千明 } \\
\\
\text { 〔総合討論〕 16:00-16:30 司会 : 野間晴雄 } \\
\text { 〔まとめ〕16:30-16:40 (小口千明 - 中村周作) }\end{array}$ & $\begin{array}{l}\text { S159 15:35-15:55〔招待講演〕 } \\
\text { 石井正好*・釜堀弘隆 (気象研) : 過去 } \\
\text { 150年間の気候再解析と大気海洋データ } \\
\text { レスキュー }\end{array}$ \\
\hline 17:00 & 終了時刻 $16: 40$ & $\begin{array}{l}\text { コメント: 塚原東吾 } \\
\text { 〔総合討論〕 } 16: 05-16: 30 \text { 座長 : 松本 淳 } \\
\text { 終了時刻 } 16: 30\end{array}$ \\
\hline
\end{tabular}




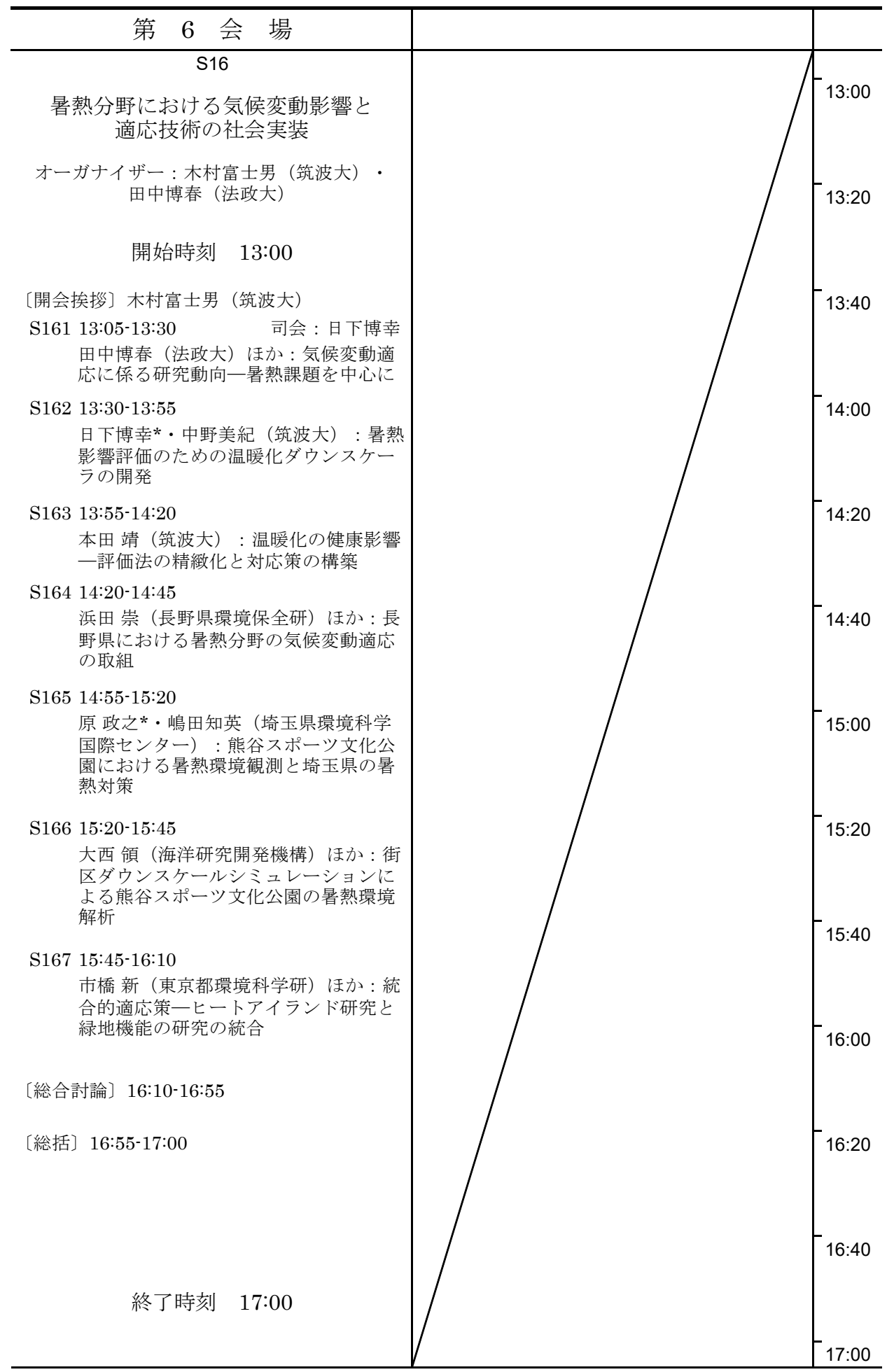


ポスター発表は，3月28日（火） 10 時〜 17 時までと 3 月 29 日（水） 9 時〜 15 時まで行います. 発表 者による説明は，3月 28 日（火） 12 時〜 12 時 30 分もしくは 3 月 29 日（水） 12 時〜 12 時 30 分の間に 行われますので，多くの会員の参加を希望します.

P001 黒木貴一(福岡教育大)ほか：2016年熊 本地震による益城町の建物被害と亀裂

P002 服部覀由未(愛知県立大)ほか: 「海から目 線」の防災一海上釣り客の津波避難行動の GPS分析

P003 田中耕市（茨城大）ほか：津波浸水予測 データに基づく避難しやすさの定量的評 価一地理的条件に基づくジオ・エバキュ エイタビリティ指標を用いて

P004 豊田瑞穂* (三重大·学) •春山成子 (三重 大) : 天井川・草津川流域 土地利用変化 と災害脆弱性一流域変化の防災活動に与 える変化に着目して

P005 南雲直子* ・江頭進治（土木研）：平成 28 年台風10号により被災した岩手県小 本川流域の地形と汇濫特性

P006 渡邊三津子（奈良女子大）ほか：紀伊半 島大水害時の実際の避難場所からみた熊 野川流域における伝統的水防施設「上が り家」の意義について

P007 森 康平（上越教育大・院）：函館大火 後の都市計画と現在の景観を結び付けた 防災学習の提案一高等学校地理の身近な 地域調査を事例として

P008 宮崎静里奈（南山大・学）ほか：立地環 境と履歴の異なる里山間での植生構造の 比較研究—愛知県海上の森と静岡県遊木 の森の事例

P009 大田千絵（奈良女子大・院）：奈良盆地 における孤立神社林の植生動態と保全一 村屋神社・鏡作神社の場合

P010 中埜貴元*(国土地理院) ・ 川又基人 (総合 研究大学院大) : 宅地盛土形状把握のため の旧地形データの効率的作成手法の検討 (その2)一仙台地区の事例

P011 阿子島 功(山形大·名誉): 史跡保存管理計 画における地形分類図の意義(3)-レー ザー測量図を利用した詳細地形分類図

P012 苅谷愛彦*(専修大) - 森田真之 (専修大· 学)：上高地・明神岳南面で発生した岩 盤崩壊とそれによる明神池の形成

P013 太田凌嘉*(専修大·学) ・苅谷愛彦 $($ 専修 大）：巨摩山地・櫛形山東麓の地すべり 地に形成された古湖沼の形成史
P014 青木 久 (東京学芸大) ほか: 琉球列島 南部, 宮古島・下地島・石垣島・黒島に 襲来した津波営力の差異一海岸段丘上の 津波石を用いた検討

P015 森山裕太*(東京学芸大・学) ・青木久 (東 京学芸大): 火山角碟岩と砂岩で構成され る波食棚の形成高度の差異一静岡県下田 市恵比須島の事例

P016 森脇広*（鹿児島大・名誉）・永迫俊郎 （鹿児島大） : 後期更新世・完新世にお ける姶良カルデラの隆起

P017 後藤健介（大阪教育大）ほか：2014年 June 27溶岩流によるPahoa周辺の詳細 土地被覆変化分析

P018 㮌島智史*(東京学芸大・学) ・青木久 (東 京学芸大) : 這い上がり砂丘の形成条件に 関する一考察—静岡県下田市田牛サンド スキー場の事例

P019 石原武志（産総研）ほか: 郡山盆地で掘 削されたオールコアの層序（第1報）

P020 鈴木理恵（信州大・学）：伊勢平野南部 における完新世後期の地形環境および人 間活動の変遷

P021 廣内大助（信州大）ほか：系魚川一静岡 構造線活断層帯神城断層北部における断 層活動

P022 高田将志（奈良女子大） : 変質したサン ゴ化石の年代推定に向けて

P023 渡邊達也*・岩㴊 翼 (北見工大) : 地中レー ダーによる沖積錐堆積構造の可視化一北 海道滝上町での例

P024 森 義孝*（新潟大・学）・奈良間千之 (新潟大) ：地下レーダー（GPR）を 用いた雪水体の地下構造

P025 関口辰夫（国土地理院）: 新潟県魚沼地 域における詳細版雪崩地形分布図につい て

P026 朝日克彦（信州大）：中部山岳における 2016 年越年性雪渓分布と動態

P027 杵淵千香子（新潟大・学）ほか：ヒマラ ヤ東部地域におけるデブリ氷河の水河上 湖の季節変動 
ポスター発表は，3月28日（火） 10時〜 17時までと3月 29 日（水） 9時〜15時まで行います. 発表 者による説明は，3月 28 日（火） 12 時〜 12 時 30 分もしくは3月 29 日（水） 12 時〜 12 時 30 分の間に 行われますので，多くの会員の参加を希望します.

\footnotetext{
P028 高玉秀之(新潟大・学)ほか: 中央アジ ア・天山山脈北部域における差分干涉 SAR解析を用いた山岳永久凍土の空間 分布

P029 松本穂高*（茨城県立土浦一高） - 小林 詢：乗鞍岳における6 年間の礫移動・地 温観測からみたソリフラクションのプロ セス

P030 浜田純一（首都大）ほか：インドネシ ア・ジャカルタ (バタビア) における過 去150年間のモンスーン降水長期変動
}

P031 赤坂郁美（専修大）ほか：19世紀後半 〜20世紀前半のマニラにおける降水の 季節変化特性

P032 井上知栄*(首都大·非常勤) - 松本 淳 (首 都大）：インドの降水量季節進行に基づ く地域区分と季節進行の長期変動

P033 村田文絵（高知大）ほか：インド・チェ ラプンジにおける降水量の長期データ解 析

P034 福島あずさ(神戸学院大)ほか:インド北東 部・アッサム州における降水特性一地点観 測データとグリッド日降水量データ(IMD4) の比較から

P035 山根悠介*（常葉大）・Rahul Mahanta (Cotton College) : インド・アッサム 州におけるシビアローカルストームの経 年変化

P036 山本晴彦（山口大）：帝国日本における 気象観測ネットワークの構築一水路部・ 海軍気象部

P037 釜堀弘隆（気象研）ほか：明治・大正期 の関東地方の区内降水量観測データレス キュー

P038 加藤内藏進（岡山大）ほか：長期データ からみる梅雨と盛夏期における東西日本 の降水の特徵に関する気候学（長崎と東 京を例とする比較解析）

P039 松本健吾（岡山大・院）ほか：梅雨最盛 期と盛夏期における東日本の大雨日の降 水特性と総観場の気候学的解析

P040 藤岡悠一郎（東北大）ほか：東シベリア における永久凍土の融解に関寸る地域住 民の認識
P041 野中直樹*（東京電機大・院）・岩井将 行（東京電機大）：Googleスプレッド シートを用いたセンシングデータのクラ ウド収集と可視化手法の提案

P042 安本晋也*・中谷友樹（立命館大）：日 本におけるデング熱の流行リスク分布と 気候変動の影響

P043 栗山知士（秋田地理学会）: 秋田県大潟 地域の気候景観をジオパークに

P044 宮本大輔（日本大・学）ほか：太平洋十 年規模振動（PDO）と総観気候系との 関係

P045 永田玲奈* ·三上岳彦（帝京大）：日降 水量データを用いた日本における台風経 路の復元（1901～2000年）

P046 岡 暁子（首都大・研）ほか：東京都と その周辺域における稒密な観測データを 用いた夏季の強雨特性

P047 片山恵梨子*（専修大・学）・赤坂郁美 (専修大) : 相模湾海風の冷却効果と小 田原市の気温分布との関係

P048 萩原誠人（専修大・学）ほか：首都圈の 夏季における気温日変化パターンの地域 特性

P049 吉田 幹 (専修大・学) ほか：諏訪湖に おける局地風と湖水温及び気温の日変化 との関係

P050 小寺浩二（法政大）ほか：神奈川県東部 における地下水の水質特性と涵養域

P051猪狩涁寛（法政大・学）ほか：浅間山周 辺地域の水環境に関する研究 (2)

P052 諸星幸子（法政大・学）ほか：十勝岳周 辺の水環境についてーリチウム濃度と地 款深部流体の関係

P053 浅見和希（法政大・院）ほか：御获山噴 火（140927）後の周辺水環境に関する 研究(5)

P054 堀内雅生（法政大 - 学）ほか: 箱根山噴 火（150629）後の周辺水環境に関する 研究(2)

P055 矢巻 剛（法政大・学）ほか：長崎県の 島嶼における水環境についての比較研究 (2) 
ポスター発表は，3月28日（火） 10時〜 17時までと 3 月 29 日（水） 9時〜15時まで行います. 発表 者による説明は，3月 28 日（火） 12 時〜 12 時 30 分もしくは 3 月 29 日（水） 12 時〜 12 時 30 分の間に 行われますので，多くの会員の参加を希望します.

\footnotetext{
P056 蒋宏偉(総合地球環境学研)ほか:ラオス 中部アランノイ住民の日常活動と健康リスク 一小型GPS及び加速度計を用いた行動調 査データの分析を中心に

P057 佐藤廉也（大阪大）ほか：ラオス中部・ アランノイの食生活と出生力一食事調査 データの分析を中心に

P058 庄子 元 (宮城教育大)ほか:干ばつ下にお ける農牧民の食糧確保と資産保有一ナミビ ア北中部Afoti村を事例に

P059 横山貴史 (立正大) : チ少共和国における先 住民マプチェの漁業一第 $8 \cdot 10$ 州の事例

P060 池口明子（横浜国立大） : ニカラグア リオグランデ流域におけるウルワの生業 活動

P061 森永由紀（明治大）ほか：モンゴル国ボ ルガン県モゴド郡の馬乳酒の評価点，物 性值, 無機成分の特徵
}

P062 渡邊敬逸（愛媛大）：土地利用変化を指 標とする無住化集落の特定方法に関する 検討一愛媛県を事例として

P063 市南文一（岡山大）：鳥取県における日 本梨栽培の変化

P064 平野七恵（農研機構）ほか：鉾田地域に お汀地下水中の硝酸態窒素濃度と土地 利用の関係

P065 植村円香（秋田大）：愛知県豊田市にお ける定年退職者への農業支援とその意義

P066 谷端 郷（立命館大）ほか：ジオデザイ ンによる京都府与謝野町の将来計画

P067 菊池慶之*(島根大) - 李 阿敏(島根大 ·研): 山陰地域における都市空間変動とマンショ ン立地一再都市化現象の出現可能性に関 する考察

P068 山元貴継*（中部大）・坪井宏晃（中部 大・学）：愛知県西春日井郡における旧 「字(小字)」とその領域の現状に関する 分析

P069 秋元菜摘（東京大 - 学術研究員）：日本 のコンパクトシティ政策と都市構造の再 考一青森市と富山市の事例に基づいて
P070 駒木伸比古（愛知大）：巨艦店出店場所 における過去の土地利用状況

P071 田中健作（豊田高専）：京阪神大都市圈 郊外のA団地における高齢住民のモビリ ティ問題

P072 石井秀明*（茨城大 - 院） - 田中耕市 （茨城大）：高齢者の買い物行動と食品 摂取への影響

P073 山神達也（和歌山大）：2010年の近畿 地方における通勤流動の基礎的検討

P074 柴岡晶(法政大・学)ほか:数量分析・バリア マップを用いた歩道のバリアの可視化一 3 区に跨がるJR飯田橋駅周辺の歩道を例に

P075 土居 晴洋*(大分大) - 柴 彦威 (北京大)： 中国都市地域における墓地の立地動向

P076 田中雅大（首都大・学振DC）：東京都 北区における参加型GISによる視覚障害 者誘導用ブロックの地理情報データベー 又構築

P077 Hou Hao (Grad Student, Univ. of Tsukuba) :Walking behavior and neighborhood environment: A case study in Tokyo Metropolitan area

P078 伊藤 悟*(金沢大)・掛上麻衣(金沢大·学)： 金沢の心象風景が北陸新幹線開業後どう 変わったか一訪問者のブログ記事を素材に した分析

P079 吉村健司 (国立民族学博物館) : 沖縄県に おけるかツ才䬺料の獲得の歴史之現在一沖 縄県水産試験場の調查・研究動向から

P080 坂本優紀（筑波大 $\cdot$ 院）ほか：長野県北 信地方における煙火産業の地域的特徵

P081 内藤 亮(東京学芸大·院)ほか: 新旧の地形 図を用いた浸水被害の変化に関する学習 方法の提案一 2015 年 9 月関東・東北豪雨 による鬼怒川水害を事例として

P082 浅田晴久（奈良女子大）：奈良県金剛山 東麓に分布するマンボの現状 
ポスター発表は，3月28日（火）10時〜17時までと3月29日（水） 9時〜15時まで行います. 発表 者による説明は，3月 28 日（火） 12 時〜 12 時30分もしくは3月 29 日（水） 12 時〜 12 時30分の間に 行われますので, 多くの会員の参加を希望します.

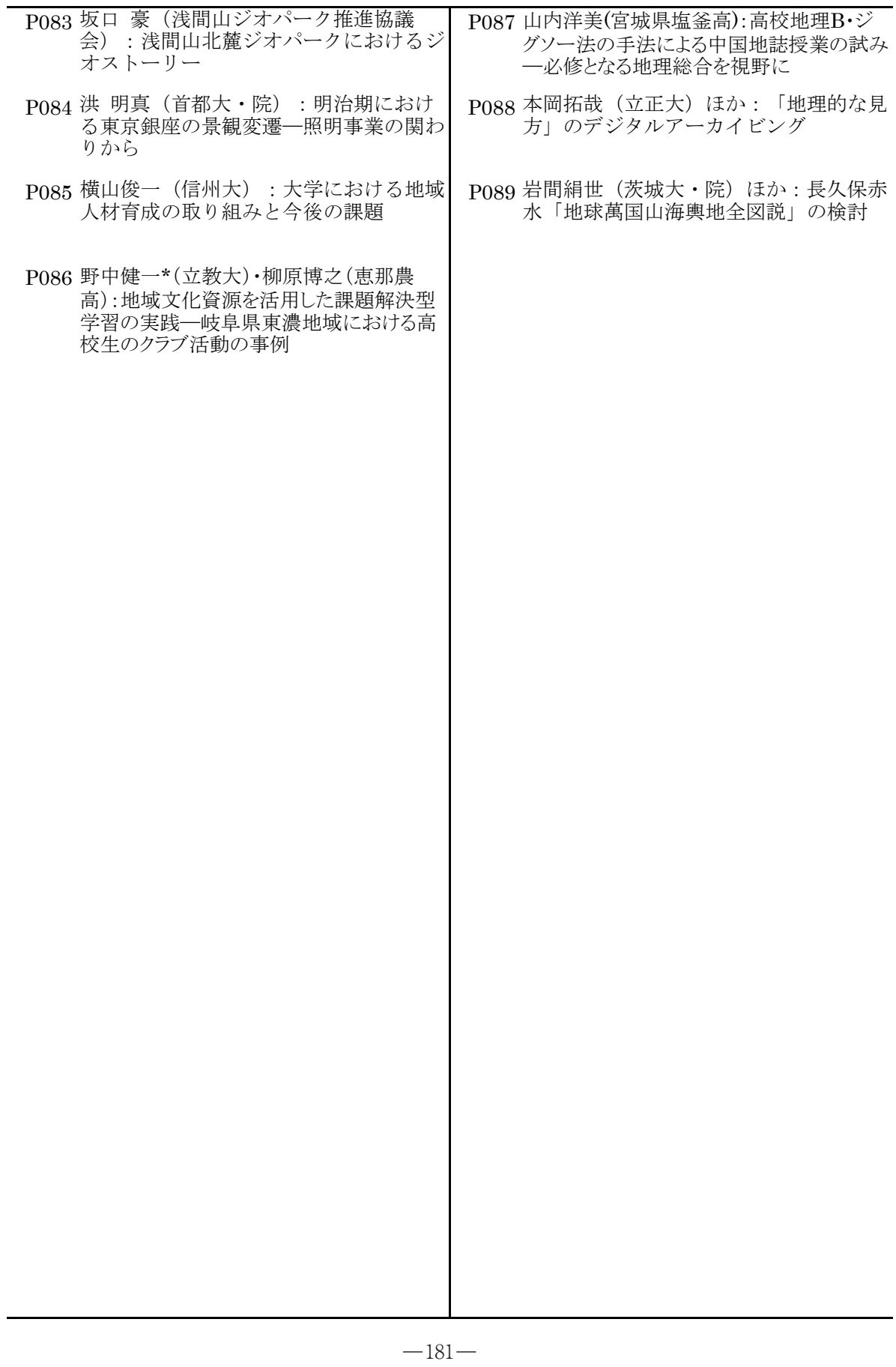




\section{7. 口頭発表座長表}

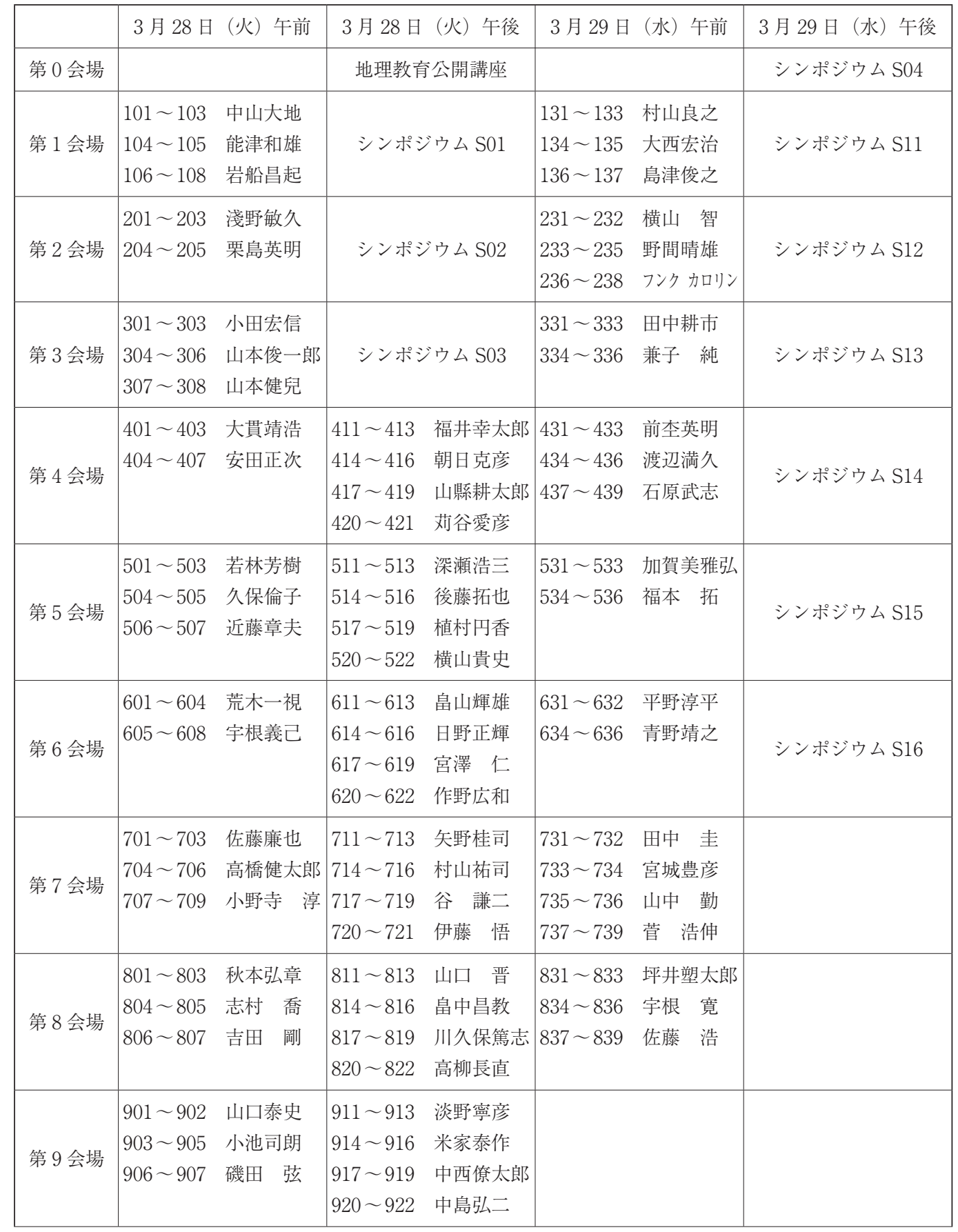




\section{春季学術大会における各研究グループの研究集会開催について}

1. 日時㧍よび会場 3 月 29 日（水）午後. $3 \mathrm{~A}$ 棟，3B棟で開催されます。会場はグループ名の後に示します.

2. 集会および話題提供

\section{-13 時 $\sim 15$ 時開催一}

中国地理研究グループ (3A213)

水と人の地誌研究グループ (3B208)

ジェンダーと空間／場所研究グループ (3B209)

\section{観光地域研究グループ (3A405)}

2016 年度観光地理学系学生論文発表会

西村圭太 (首都大・学)：埼玉県川越市におけるコミュニティサイクル利用観光者の観光行動特性と観光 行動に影響を与える要素

吉岡誉将 (首都大・学)：サッカーファンのアウエイ訪問動機と観光行動——Jリーグクラブファンを事例 として

田中健太 (首都大・学)：西オーストラリア州・パース都市圈の MICE 産業に抒ける宿泊施設の立地変化 とその役割

植手友浩 (三重大・学)：愛知県名古屋市西区円頓寺界隈に抢ける観光まちづくりの展開——商店街組織 の活動に着目して

深澤千帆（㧍茶の水女子大・学）：事業者の内発的なインバウンド観光振興のための地域内連携——みな かみ町の旅館と関係組織の取り組みを例に

小野坂知子（お茶の水女子大・学）：和歌からみたコンテンッ・ッーリズムの枠組み——歌枕の類型表現 と旅の形成過程に着目して

下尾崎一仁 (名桜大・学)：鹿児島県における産業観光としての焼酎蔵巡りの展開可能性に関する考察 ——焼酎事業者の見学者受け入れ態勢に着目して

岡田浩平 (筑波大・学)：しまなみ海道開通による観光業の変遷——愛媛県大三島を事例として

魏 新宇 (広島大・院)：観光者の情報発信による新しいコンテンツ・ッーリズム——広島県大久野島の 観光ブームを例として

GIS と社会研究グループ (3A407)

テーマ：「参加型 GIS の理論と応用」について（座談会）

\section{地域連携活動研究グループ (3A408)}

櫛引素夫（青森大）：教育・研究と地域貢献活動の融合——『道の駅』, JR 東日本との連携から

山田浩久 (山形大)：自治体から大学への委託研究がもたらす効果と課題

\section{都市地理学研究グループ (3A410)}

秋元菜摘（東京大・院）：日本のコンパクトシティ政策に関するシミュレーション分析からの研究

池田真利子 (筑波大・非)：インナーシティ地区に扔けるジェントリフィケーションの移動性——ポスト 分断都市ベルリンを事例に

\section{国際経済・経営地理学研究グループ (3B401)}

Rolf Schlunze (Ritsumeikan Univ.): A geographical perspective of boundary spanning: An actorcentered approach in the avenue of management geography".

\section{近代日本の地域形成研究グループ (3B406)}

\section{-15 時 $\sim 17$ 時開催一}

エスニック地理学研究グループ (3A213)

高橋昂輝（日本大・院）：トロントに扔ける業務改善自治地区 BIA とエスニックネイバーフッド 山下清海（筑波大）：自己流のエスニック地理学を回顧して 
日本における亜高山・高山域の植生・環境変遷史研究グループ（3B208）

少子高齢化と地域問題研究グループ (3B209)

離島地域研究グループ (3A305)

筒井 裕 (帝京大)：三宅島に扔ける祭礼文化の継承に関する調查報告——神着・阿古地区を事例に

須山 聡（駒澤大）：奄美大島へのまなざし——学生に対するイメージ調査に基づいて

持続可能な交通システム研究グループ (3A405)

健康地理研究グループ (3A407)

岩間信之（茨城キリスト教大）：地方都市におけるフードデザート問題対策事業の検討

荒堀智彦 (首都大学東京・院)：感染症サーベイランスに㧈ける疾病地図の利活用と健康危機管理に向け た課題

「新しい公共」の地理学研究グループ（3A408）

美谷 薰 (福岡県立大): 水道料金の地域差とその要因に関する一考察

都市の社会・文化地理学研究グループ (3A410)

テーマ: 東京オリンピックに向けて考える

小泉＼cjkstart諒（神奈川大）：近年のロンドン都市計画事業と大規模イベントの利用

杉山和明（流通経済大）：伊勢志摩地域におけるサミット後の観光とセキュリティ

地図・絵図資料の歴史 GIS 研究グループ（3A415）

宇根 寞 (国土地理院)：大規模地震に対する国土地理院の取り組み——災害対応を支える新技術

\section{産業経済の地理学研究グループ (3B401)}

流通・消費の地理学研究グループ (3B406)

安倉良二 (立命館大・非)：大学のキャンパス新設を契機とする学生参加による中心商店街のまちづくり 一大阪府八尾市を事例に

根田克彦（奈良教育大）：ロンドンに扔ける小売店の立地政策とインナーシティの再生 